\title{
Hizkuntzen arteko elkarreragina: euskara, gaztelania eta ingelesezko ekoizpen idatziak
}

\author{
Cross-linguistic influence: written productions in Basque, \\ Spanish and English
}

\author{
Itxaro Etxague Goia*, Karin van der Worp \\ Hezkuntza, Filosofia eta Antropologia Fakultatea \\ Euskal Herriko Unibertsitatea, Donostia, Gipuzkoa
}

\begin{abstract}
LABURPENA: Elebitasun eta eleaniztasunaren gaia bai ikerketan, bai maila sozialean, baita eskola testuinguruetan ere, gero eta interes biziagoa pizten ari da egun; izan ere, zenbait ikertzailek parametro elebakarretatik ikuspegi holistiko baterako aldaketa gertatzen ari dela nabarmentzen dute (Cenoz eta Gorter, 2015; De Angelis, 2007; Ortega, 2019; Ortega eta Carson, 2010; Soltero - Gonzalez, Escamila eta Hopewell, 2012). Lan honen helburua da hiztun eleaniztunak idatzizko ekoizpenean gauzatzen dituen hizkuntza elkarreraginak identifikatzea, sailkatzea eta ikuspegi holistiko eta bateratu batetik aztertzea. Horretarako, Nafarroako Foru Komunitateko Derrigorrezko Bigarren Hezkuntzako 4. mailako 20 ikasleren euskarazko, gaztelaniazko eta ingelesezko testuak aztertu dira. Emaitzek transferentzia mota gehienak ingelesezko testuetan egin direla erakutsi arren, maiztasun gehienarekin euskarazko testuetan gauzatu direla erakusten dute. Era berean, mota gutxien eta urrien errepikatuak gaztelaniazko testuetan agertu dira. Ikerketa honek hiztun eleaniztunak hizkuntzak etengabeko elkarreraginean daudela erakusten du, bai hiztunaren hizkuntza-jabekuntzan, bai garapenean, baita ekoizpenetan ere.
\end{abstract}

GAKO-HITZAK: hizkuntza elkarreragina, transferentzia linguistikoa, idatzizko ekoizpena, hirugarren hizkuntza, Bigarren Hezkuntza.

ABSTRACT: The topics of bilingualism and multilingualism are becoming increasingly popular in research as well as in social and educational contexts. Some researchers state that a turn from a monolingual view to a more holistic view is taking place (Cenoz and Gorter, 2015; De Angelis, 2007; Ortega, 2019; Ortega and Carson, 2010; Soltero - Gonzalez, Escamila and Hopewell, 2012). The aim of this study is to identify, classify and analyse the cross-linguistic transfer of multilingual writers from a holistic perspective. For this purpose, essays in Basque, Spanish and English of 20 secondary education students from the Foral Community of Navarre are examined. The results show that although the highest amount of different types of cross-linguistic transfers are found in the English essays, crosslinguistic transfers appeared with the highest frequency in Basque texts. In addition, the least frequent ones appeared in Spanish texts. This study shows that the languages of a multilingual speaker are in constant interaction, both in the language acquisition and development of the speaker, as well as in the language production.

KEYWORDS: language interaction, language transfer, written production, third language, Secondary Education.

\footnotetext{
* Harremanetan jartzeko / Corresponding author: Itxaro Etxague Goia. Euskal Herriko Unibertsitatea. Didaktika eta Eskola Antolakuntza. Hezkuntza, Filosofia eta Antropologia Fakultatea. Tolosa hiribidea, 70. 20018. Donostia. Gipuzkoa. - Itxaro.etxague@ ehu.eus
}

Nola aipatu / How to cite: Etxague Goia, Itxaro; van der Worp, Karin. (2020). «Hizkuntzen arteko elkarreragina: euskara, gaztelania eta ingelesezko ekoizpen idatziak». Tantak, 32(2), 95-126. (https://doi.org/10.1387/tantak.21826).

Jasotze-data: 2020/06/16; Onartze-data: 2020/09/30

ISSN 0214-9753 - elSSN 2444-3581 / (c) 2020 UPV/EHU

(c) (i) Obra hau Creative Commons Atribución 4.0 Internacional-en




\section{SARRERA}

Elebitasun eta eleaniztasunaren inguruko gaiak ikerlari, irakasle, politikari eta hiztunen ahotan daude egun. Parametro eta ideia elebakarretatik ikuspegi holistiko eta eleaniztun baterako aldaketa gertatzen ari dela azpimarratzen dute hainbat autorek, bai ikerketan, bai testuinguru sozialean, baita eskola testuinguruan ere (Cenoz eta Gorter, 2015; De Angelis, 2007; Ortega, 2019; Ortega eta Carson, 2010; Soltero - Gonzalez, Escamila eta Hopewell, 2012).

Horrela, Cenoz eta Gorter-ek $(2011,2014)$ «Focus on Multilingualism» ikuspegi holistikoa proposatzen dute. Ikuspegi horrek hiztun eleaniztunaren eta hizkuntza-ikasle eleaniztunaren errepertorio linguistikoari bere osotasunean begiratzen dio, baita horiek ikertu, irakatsi edo ebaluatzeko garaian elkarren arteko harreman eta erlazioei ere. Izan ere, hiztun eleaniztuna berariazkoak dituen tasunen jabe da; tasun horiek, gainera, bai hizkuntzen jabekuntzan, bai horien garapenean eta baita ekoizpen linguistikoetan ere eragina izan dezakete. Ekoizpen horietan, hiztunaren errepertorio linguistikoa osatzen duten elementu linguistikoak etengabeko elkarreraginean egonik, hizkuntzen arteko elkarreraginak azaleratu daitezke (Arocena, 2017; Cenoz eta Gorter, 2011; Orcasitas, 2018).

Eredu hori da, hain zuzen ere, lan honetarako aukeratu dena. Lan honen helburua da hiztun eleaniztunek idatzizko ekoizpenean gauzatu dituzten hizkuntza elkarreraginak identifikatzea, sailkatzea eta aztertzea. Zehazki, hiztun eleaniztunak euskaraz, gaztelaniaz eta ingelesezko idatzizko testuetan zein transferentzia mota egiten dituen identifikatu nahi da. Halaber, bi analisi mota gauzatu nahi dira: batetik, transferentzia hauek maiztasunaren arabera ordenatzea eta, bertzetik, transferentzien maiztasuna hiztunak idazteko erraztasun handiena duen hizkuntzaren arabera sailkatzea eta alderatzea. Nafarroako Foru Komunitateko Bigarren Hezkuntzako ikastetxe publiko batean jaso dira ikerketa honetarako datuak, 4. mailako D ereduko ikasleen ekoizpenak, hain zuzen ere. Horrela, ikuspegi holistiko batetik zuzendutako ikerlana izanen da hau, ikaslearen errepertorio linguistiko osoa kontuan hartuz hizkuntza-elkarreraginak aztertuko dituena, hain justu ere. Ikerketa honetan, beraz, idatziaren ebaluazioan hiztun eleaniztuna eta haren ekoizpena osotasunean aztertzearen beharrari erantzun nahi izan zaio, hizkuntzen arteko elkarreragina ulertzeko. Izan ere, elkarreragin linguistikoa kontuan hartzea eta ebaluazio holistikorako diseinaturiko tresnak erabiltzea defendatu nahi du lan honek.

\section{OINARRI TEORIKOAK}

\section{1. «Focus on Multilingualism»: hurbilpen holistikoa}

Cenoz eta Gorter-ek $(2011,2014)$ honela definitzen dute «Focus on Multilingualism»: «Focus on Multilingualism is an approach for teaching 
and research in multilingual education that relates the way multilingual students use their communicative resources in spontaneous conversation to the way languages are learnt and taught at school» (Cenoz eta Gorter, 2014,242 . or.). Horrela, bada, hiztun eleaniztuna era holistikoan aztertzea proposatzen du, hau da, askotariko egoera komunikatiboei erantzuna emateko berariazko errekurtso linguistikoak dituen pertsona eleaniztun gisa. Era horretan, hiztun eleaniztuna hizkuntza jakin bateko jatorrizko hiztunarekin alderatu ezin den subjektua dela azalduko da. Ikuspegi hori hiru zutabe nagusitan oinarritzen da (Cenoz eta Gorter, 2011, 2014): hiztun eleaniztuna, errepertorio linguistikoa eta testuinguru soziala.

Hiztun eleaniztunari dagokionez, tradizionalki, hiztun mota horren gaitasuna edo konpetentzia linguistikoa berezko hiztun edo hiztun natibo idealarekin konparatu izan ohi da, eta eleaniztuna den hiztun baten gaitasun linguistikoa ikuspegi elebakarraren arau eta ereduekin neurtu. Horrek hiztunarengan porrot sentsazio eta konfiantza falta sorrarazteaz gain, hizkuntzaren ikaskuntza prozesua iritsi ezinezko helmuga baterantz bideratzen du. Aldiz, «Focus on Multilingualism» ikuspegia joera elebakar horren erantzun gisa aurkezten da, jatorrizko hiztunaren irizpidea alde batera utziz, ikuspuntu holistiko bat erabiliz eta hiztun eleaniztunari propioak dituen ezaugarri linguistikoak aitortuz. Izan ere, hiztun eleaniztunak bereak dituen lanabes linguistikoak erabiltzen ditu komunikatzeko eta, autoreek dioten moduan, «these practices contribute to the development of their multilingual and multicultural identities» (Gorter, Zenotz, Etxague eta Cenoz, 2014, 297. or.). Ortegak (2019) ere ideia horrekin bat egiten du eta «the native speaker bias» aipatzen du bere lanean, «which holds that owning a language from birth results in a form of linguistic competence superior to the competencies that may develop through any other means over the life trajectory» (Ortega, 2019, 24. or). Autorearen arabera, ikuspegi edo joera horrek hizkuntza ikaslea porrotera kondenatuta egonen balitz bezala irudikatzen du, ezinezkoa izanen baitzaio hiztun natibo ideal horren helmugara iristea.

Bertzalde, Li Wei eta Wu-k (2009, 193. or.), oro har, kode aldaketa hiztun eleaniztunaren ezaugarri bereizgarrienetako bat dela azpimarratu arren, eskola praktiketan hizkuntza banaketaren ideologia zorrozki errotuta dagoela diote, horrela hizkuntzen arteko elkarreragina saihesteko joerak nabarmentzen direla. «Focus on Multilingualism» ereduak hiztun eleaniztunen hizkuntza guztiak sistema oso eta beraren barruan aurkezten ditu. Osotasun horrek, hizkuntzen arteko mugak samurtu edo malgutzeaz gain, hizkuntzen arteko elkarreraginak azaltzen ditu, baita hizkuntza-jabekuntza eta -garapen prozesuetan bata bertzearen lagungarri diren azpi-sistemak direla erakutsi ere. Horrela, bada, aipaturiko elkarreragin hori ulertzeko eta azaltzeko, hiztunaren errepertorio linguistiko osoa kontuan hartzea defendatzen du eredu horrek.

Azkenik, eleaniztasunak, dimentsio linguistikoaz gain, dimentsio soziala ere baduela kontuan hartu beharrekoa da. Eredu honek, beraz, hiztun eleaniztunak bere gaitasun linguistikoa testuinguru sozialetan gertatuko diren el- 
karreraginetan garatuko direla azaltzen du. Era berean, elkarreragin horietan sortutako behar komunikatiboei erantzuteko, beren errepertorio linguistiko osoa osatzen duten baliabide linguistikoak erabiliko dituzte. Eleaniztunen hizkuntza-praktika definituko duena testuinguru jakin bat izanen da, bada.

Laburbilduz, eredu horrek hiztun eleaniztunaren jardun linguistikoa bere osotasunean azaltzen du, eta lan honetan landuko diren idatzizko hizkuntza elkarreragin linguistikoak ulertzeko eta azaltzeko baliagarri izan da.

Eredu horren erabilgarritasun eta balioaren erakusgarrietako bat dugu Cenoz eta Gorter-ek (2011) egindako ondorengo ikerketa hau. Autoreek Bigarren Hezkuntzako eta lehen hizkuntza (H1) gisa euskara edo gaztelania duten 165 ikasleren idatzizko testuak aztertu dituzte. Testu horietan azaleratzen diren norabide anitzeko hizkuntza transferentziei, ikaslearen idatzizko gaitasun orokorrei eta egoera informaletan gertatutako hizkuntza nahasketa edo gurutzaketei erreparatzen diete. Horrela, bada, ikasle eleaniztunak zenbait elementu linguistiko, bai gramatikalak bai lexikalak, hizkuntza batetik bertzera transferitzen dituela ondorioztatzen dute, norabide guztietan, gainera (ikusi baita ere Soltero - Gonzalez, Escamila eta Hopewell, 2011). Horretaz gain, analisi kualitatiboak erakusten duen moduan, hainbat ikaslek idatzirako estrategia orokor berdina erabiltzen dute hiru hizkuntzetan, hots, testu genero berdina, testu eduki berdintsuarekin bideratua, etab. Hizkuntzen arteko idatzizko gaitasunaren jakintza partekatuaren erakusgarrietako bat izateaz gain, «Focus on Multilingualism» ereduaren baliagarritasuna erakusten du ikerketa honek, baita hiztun eleaniztuna bere osotasunean aztertzeak dituen onurak erakutsi ere.

Aipaturiko ikerketa hori (Cenoz eta Gorter, 2011) hizkuntza idatziaren jardunean gertatzen diren hizkuntzen arteko elkarreraginaren erakusgarrietako bat da: elkarreragin hori dinamikoa dela eta horren eraginez hizkuntzatransferentziak norabide desberdinetan gerta daitezkeela erakusten dute. Orobat, hurbilpen eleaniztun baten baliagarritasuna ere nabarmentzen du (ikusi, baita ere, Kobayashi eta Rinnert, 2012). Hizkuntzen arteko elkarreragina da, hain justu ere, jarraian landuko dena.

\subsection{Hizkuntzen arteko elkarreragina}

Hizkuntzen arteko elkarreraginaren (crosslinguistic influence) ikerketak norbanakoak duen jakintza linguistikoak xede-hizkuntzaren ekoizpen, ulermen eta garapenean nola eta zer baldintzetan eragiten duen ikertzea du helburu (De Angelis, 2007). Autorearen arabera, crosslinguistic influence terminoa 80ko hamarkadaren erdialdera proposatu zen (ikus Kellerman, 1984; Sharwood-Smith, 1983) xede-hizkuntzan gerta daitezkeen askotariko elkarreraginak biltzen dituen termino gisa, hala nola transferentzia, interferentzia, saihestea (avoidance), maileguen erabilera eta bigarren hizkuntzarekin (H2) lotutako hizkuntza galera (De Angelis, 2007, 19 or.). 
Horrela, bada, hizkuntzen arteko elkarreraginaren hainbat definizio aurkitu ditzakegu literaturan. Odlin-ek (1989), errate baterako, honako adiera hau ematen dio: «the influence resulting from similarities and differences between the target language and any other language that has been previously (and perhaps imperfectly) acquired»(Odlin, 1989, 27. or.). Sharwood-Smith-ek (1994), halaber, honela definitzen du hizkuntzen arteko elkarreragina: «the influence of the mother tongue on the learner's performance in and/or development of a given target language; by extension, it also means the influence of any «other tongue» known to the learner of that target language» (1994, 198. or.). Azkenik, Gass eta Selinker-en (1983) definizioa ekarriko da lerrootara: «for most researchers, language transfer is the use of native language (or other language) knowledge - in some as yet unclear way - in the acquisition of second (or additional) language» (Gass eta Selinker, 1983, 372. or.).

Definizio horiek aztertuta, hizkuntzen arteko elkarreragina eskuarki bi hizkuntza batzen dituen fenomeno gisa ikusi izan dela erran daiteke (De Angelis, 2007): batetik, iturri hizkuntza eta, bertzetik, xede-hizkuntza. Elkarreragin mota hori one-to-one type of association gisa izendatzen du De Angelis-ek (2007), hots, iturri hizkuntza eta xede-hizkuntzaren arteko elkarreragina. Ordea, autoreak bigarren mota bat ere identifikatu eta manyto-one type moduan izendatzen $\mathrm{du}$, hau da, xede-hizkuntzan hizkuntza bat baino gehiagoren aldi bereko elkarreragina gertatzea (De Angelis, 2007, 21. or.). Horrela, bada, hirugarren hizkuntzan (H3) gerta daitezkeen hizkuntza elkarreraginak landuko dira jarraian. Horretarako, H3n jabekuntza prozesua eta garapena izanen dira gidalerro.

\subsubsection{Hizkuntzen arteko elkarreragina hirugarren hizkuntzan}

$\mathrm{H} 3 \mathrm{n}$ jabekuntza prozesua hainbat ikuspuntutatik iker daiteke (soziolinguistikoa, psikolinguistikoa, ikuspegi generatibista...) eta emaitzak tradizio bakoitzaren arabera interpretatu. Ikerlarien artean hizkuntza-jabekuntzaren lehenbiziko etapan eta garapen-etapetan H1ean jabekuntza eta $\mathrm{H} 2$ n jabekuntza prozesuak desberdinak direla onartua dagoen arren, jabekuntzaren hasierako etapan hiztunak eskuragarri dituen elementu linguistikoak ezinbertzean ezberdinak baitira, ez dago H3n jabekuntzaren inguruko adostasunik (Rothman eta Cabrelli, 2010, 190. or.). Autoreen arabera, hainbat ikertzailek H3n jabekuntza prozesua H2ren jabekuntza prozesuaren errepikapena dela defendatzen duen ikerlerroaren aldeko jarrera hartu badute ere, $\mathrm{H} 2 \mathrm{n}$ jabekuntza prozesuaren eta H3n jabekuntza prozesuaren artean bereizketa egitea beharrezkoa da: «over the last decade or so, it has been acknowledged that the existence of two already-acquired language systems at the onset of L3 acquisition makes this process unique and worthy of study in its own right» (Rothman eta Cabrelli, 2010, 190. or.). Jessner-ek (2008) ere bat egiten du ideia horrekin, H3 ikasten ari den hiztunak jadanik atzerriko hizkuntza baten ikasketa prozesuaren berri baduela adieraziz: «The L3 learner already knows about the foreign language learning 
process and has (...) gathered individual techniques and strategies to deal with such a situation with differing degrees of success» (Jessner, 2008, 23. or.).

H3n jabekuntza prozesuak zein H3n gertatzen diren hizkuntza-elkarreraginak bere-bereak dituen zenbait ezaugarri dituela erran dezakegu, bada. Hizkuntza-elkarreragin hauek gertatzeko, ordea, faktore eragile batzuk kontuan hartu behar dira. Hala bada, jarraian, hirugarren hizkuntzaren ekoizpenean gerta daitezkeen elkarreraginen faktore eragileak jorratuko dira. Horretarako, Forsyth-en (2014) sailkapena hartuko da oinarri, zeinak bortz faktore eragile izendatzen baitituen: antzekotasun tipologia edo distantzia linguistikoa, faktore afektibo edo kognitiboak, bigarren hizkuntzaren gaitasun maila eta esposizioa, berritasuna eta jabetze ordena eta, azkenik, adina.

1. Antzekotasun tipologikoa edo distantzia linguistikoa: Kellerman izan zen tipologia antzekotasuna edo «psikotipologia» terminoak mahai gainera ekarri zituena bere 1983ko ikerlanean. Horren arabera, elkarreragina gertatzeko aukera gehiago izanen da $\mathrm{H} 2$ tipologikoki H3tik hurbil badago, batez ere $\mathrm{H} 1$ bertze bi hizkuntzetatik urrun baldin badago. Hori hiztunaren H1 hizkuntza ez-indoeuroparra denean gerta daiteke, ekialdeko hiztunek ingelesa eta frantsesa ikasten dituztenean (ikusi Ringbom, 2001) edo, euskararen kasuan bezala, H1 hizkuntza gutxitua denean, kasu. Ringbom-ek (2001), gainera, faktore eragile horrek batez ere lexikoari eragiten diola zehazten du.

Dena den, De Angelis-en (2001) arabera, hizkuntzen arteko distantzia tipologikoaz hiztunak dituen hautemate edo pertzepzioek hizkuntzen arteko elkarreraginean eragin dezakeen arren, pertzepzio horiek ez dute zertan benetako distantzia tipologikoarekin bat egin (De Angelis, 2001, 55 or.). Hizkuntza tipologiaren azterketaren haritik honako hau gehitzen du Cenozek (2003): «language typology has a historical origin and cannot be studied without considering the history of the language and the language contact situations» (Cenoz, 2003, 105. or.).

2. Faktore afektibo edo kognitiboak: Hammarberg-ek (2001) identifikazio kulturala edo «cultural identification» kontzeptuarekin lotzen du faktore hori, hiztunak bere hizkuntza bakoitzarekin sentitzen duen identifikazio kulturalaren mailarekin, hain justu ere. Dena den, ikerketek erakutsi dutenaren arabera, idatziarekin baino ahozko ekoizpenarekin lotuago dagoen faktorea dugu hau. Ahozko ekoizpenean kokaturik, Kellerman-ek (1995) testuinguru formal eta informalen arteko bereizketa nabarmendu zuen, eta ikaslea eskola testuinguruan kokatu. Horri loturik, De Angelis-ek (2007) hizkuntza-antsietatearen eragina aipatzen du, testuinguru formalak, porroterako beldurrak zein ikasleak sentitzen duen presioak estresa eragin baitiezaioke hiztunari eta horrek $\mathrm{H} 2$ n elkarreraginak murriztu.

3. Bigarren hizkuntzaren gaitasun maila eta esposizioa: Hammarberg-en (2001) arabera, hiztunak H2n duen gaitasun mailak, bai eta bere jabekuntza eta testuinguru naturaletako erabilerak ere, H2k H3n duen elkarreraginean eragin dezake (Hammarberg, 2001). Ringbom-ek (2001), halaber, H2n elkarreragin maila $\mathrm{H} 2 \mathrm{n}$ gaitasun mailaren araberakoa izateaz gain, hiztunak 
H2arekiko duen esposizio mailaren araberakoa ere badela dio, batez ere elkarreragin gramatikalean (Ringbom, 2001). Hizkuntza gaitasunaren haritik, De Angelis eta Selinker-ek (2001) hiztunak bere gaitasun mailaren inguruan pentsatzen duena ere, hots, pertzepzio pertsonala, faktore eragilea izan daitekeela diote: «At the initial stages of third or additional language acquisition, a learner may perceive his/her own competence to be too low to be willing to risk incorporating previous linguistic knowledge in the target language» (De Angelis and Selinker, 2001, 56. or.). Autore horien arabera, beraz, $\mathrm{H} 2 \mathrm{n}$ gaitasun maila faktore eragile subjektiboa ere izan daiteke zenbait kasutan.

4. Berritasuna eta jabetze ordena: Hammarberg-ek (2001) H3n ekoizpenetan $\mathrm{H} 1$ baino gehiago $\mathrm{H} 2$ aktibatzeko joera identifikatu zuen. Jabetza ordenari dagokionez, Dewaele-k 1998 an egindako ikerlana da aipagai. Bertan, nederlandera $\mathrm{H} 1$ eta ingelesa $\mathrm{H} 2$ edo $\mathrm{H} 3$ zuten hiztunek frantsesezko ahozko ekoizpenetan asmatutako elementu lexikoak aztertu zituen, eta horiek hiztunaren $\mathrm{H} 2$ eta $\mathrm{H} 3 n$ jabetza-ordenaren araberakoak zirela erakutsi. $\mathrm{H} 2 \mathrm{n}$ jabekuntzak, bada, hizkuntza prozesamenduan eragin dezake, Cenozek (2003, 106. or) dioen bezala «multilinguals could use different processing and acquisition mechanisms for second languages as compared to first languages».

5. Adina: Selinker eta Lakshmanan-en (1993) arabera, bigarren hizkuntzaren jabekuntza prozesuaren azterlana, oro har, Chomsky-ren Gramatika Unibertsalaren (1957) teoriaren pean dago, hiztunaren H1en baino horrek jasotzen duen inputa azpimarratuz eta, horrela, transferentzia positiboen probabilitatea murriztuz. Hirugarren hizkuntzara hedatuz, ordea, Cenozek (2001) zazpi eta 15 urte bitarteko euskara eta gaztelaniadunen ekoizpenetan elkarreragin linguistiko gehiago identifikatu zituen hiztun helduagoen artean gazteen artean baino. Hala ere, faktore kognitiboekin baino, helduagoek izan dezaketen kontzientzia edo jakintza metalinguistikoarekin eta distantzia linguistikoari buruzko jakintzarekin lotuago egon daiteke hori (Cenoz, 2001).

Hizkuntzen arteko elkarreraginean zerk lagundu eta indartu lezakeen ikusi ondotik, elkarreragin horren emaitza hizkuntzaren zein ataletan gerta daitekeen landuko da. De Angelis-en (2007) lana hartuko da, hain zuzen ere, zati honen gidalerrotzat.

\subsubsection{Hizkuntzen arteko elkarreragina: hizkuntzaren atalak}

Hizkuntzen arteko elkarreraginak hizkuntzaren dimentsio edo atal ezberdinetan gerta daitezke. Jarraian, hizkuntzaren lau atal nagusiei erreparatuko zaie, hots, lexikoari, fonetika eta fonologiari, morfologiari eta sintaxiari, eta atal bakoitzean hizkuntza-elkarreragina jorratu. Horretarako, De Angelis-en (2007) lanean aurkeztutako sailkapena hartuko da oinarri. Hona, bada, hizkuntzaren lau atalak:

1. Lexikoa: autorearen arabera, $\mathrm{H} 3 \mathrm{n}$ identifika daitekeen elkarreragin linguistikoa bereiziki nabarmena da lexikoan edo hiztegian. Horrela, Ring- 
bom-en (1987) lanean oinarriturik, hiztunen ekoizpenetan ager daitezkeen elkarreragin lexikoak bi taldetan sailkatzen ditu: transferentzia lexikoak, batetik, eta maileguak, bertzetik. Edonola ere, Ringbom-ek (1987, 2001) adieraren transferentzia gaitasun maila ona duen hizkuntzetara mugatzen $\mathrm{du}$, eta hiztunaren lehen hizkuntzan edo gaitasun maila ona duen hizkuntzetan gertatzen den fenomeno gisa sailkatu.

Bertzalde, hainbat ikerlanek lexikoaren elkarreraginean hitzaren karga semantikoak eragina duela proposatzen dute. Izan ere, eduki hitzak edo content words (izenak, aditzak, zenbatzaileak, izenondoak eta aditzondoak) eta funtzio hitzak edo function words deiturikoak (preposizioak, determinatzaileak, konjuntzioak eta izenordainak) ez dira modu berean erabiltzen ekoizpen prozesuan zehar (De Angelis, 2007, 44. or.).

2. Fonetika eta fonologia: oro har, hiztunak ama-hizkuntzaren ezaugarri fonetiko zenbait gordetzen ditu atzerriko hizkuntza batean mintzatzeko orduan. Horregatik, autorearen hitzetan, ama-hizkuntza ez den edo diren hizkuntza(k) ez dira, orokorrean, elkarreragin fonetikoaren jatorri-hizkuntza nabarmenak izaten. Nolanahi ere, badago elkarreragina gertatzeko aukerarik (ikusi Hammarberg eta Hammarberg, 1993).

3. Morfologia: De Angelis-en (2007) arabera, nolabaiteko eszeptizismoz ikusten dira flexio-morfologia eta morfologia elkartuaren transferentziak. Dena den, berriki eginiko hainbat ikerketa enpirikok ama-hizkuntza ez den gainerako hizkuntzetan jatorria duten elkarreragin morfologikoak identifikatu dituzte eta, beraz, tradizionalki pentsatu izan den bezain immunea ez dela erakutsi (De Angelis, 2007). Bouvy-ren (2000) lana dugu horren adibideetako bat. Bouvy-k (2000) bi hizkuntza ez natiboren artean gertatutako transferentzia morfo-semantikoak identifikatu zituen nederlandera eta ingelesaren artean. Hala bada, nederlanderaren plural-markaren arauak eta atzizkiak ingelesean erabiliak izan zirela aztertu zuen.

4. Sintaxia: bigarren hizkuntzaren jabekuntzari erreparatuz gero, sintaxian oinarritzen diren eta lehen hizkuntzaren elkarreraginari begiratzen dioten bi teoria nagusi aipa daitezke: «Minimal Trees» hypothesis (Vainikka eta Young-Scholten, 1996) eta «Full Transfer / Full Access» hypothesis (Schwartz eta Sprouse, 1996). Bigarren hizkuntzaren sintaxiaren jabekuntzaren garapenean oinarritzen diren bi eredu horiek, ordea, gramatikaren eraikuntzari buruz hipotesi desberdinak proposatzen dituzte, baita bigarren hizkuntzaren hasierako etaparen nolakotasunari buruzkoak ere. Edonola ere, ezin ahantzi lan honetan hirugarren hizkuntzen arteko elkarreraginari buruz ari garela.

Hizkuntza idatzia izanen da hurrengo aipagaia, lan honen aztergaiak idatzizko ekoizpena eta prozesu horretan azaleratutako elkarreragin linguistikoak baitira. Zehazki, hizkuntza idatziaren ebaluazioa eta analisia jorratuko dira, jardun horretarako ikuspegi holistiko baten beharra azpimarratuz. 


\subsection{Hizkuntza idatzia eta haren ebaluazioa}

Velasco eta García-k (2014) «ekoizpen idatziaren ariketa» hainbat etapatan osatutako ariketa gisa definitzen dute, hau da, «defined by stages in which the writer moves back and forth through planning, drafting, and producing a final version» (Velasco eta García, 2014, 10. or.). Horrela, hiztun eleaniztunak berariazkoak dituen arazo-ebazpen baliabideak erabiltzen ditu ariketa edo jardun horri aurre egiteko, ekoitzitako testuan bereak dituen ezaugarri zenbait azaleratuz, hots, elebakarren ekoizpen idatzietan agertzen ez diren ezaugarriak agertuz.

Ezaugarri bereizgarri horiek kontuan izanik, hiztun eleaniztunaren idatzizko gaitasuna eta hori ebaluatzeari dagokionean ere foku aldaketa bat eman dela erran daiteke. Horrela, Soltero - Gonzalez, Escamila eta Hopewell-ek (2012) «holistic bilingual view»-rantz, hots, elebitasun edo eleaniztasun holistikoranzko aldaketa, idatzizko ekoizpenaren ebaluaketan nola gauzatu daitekeen erakusten dute beren ikerketan: horretarako, ondoko taula hau aurkezten dute autoreek (Soltero - Gonzalez, Escamila eta Hopewell, 2012):

\section{1. taula}

\section{Parallel monolingualism vs. Holistic bilingualism. (Soltero-González, Escamila eta Hopewell, 2012) lanetik egokitua}

\begin{tabular}{|c|c|}
\hline Parallel Monolingualism & Holistic Bilingualism \\
\hline $\begin{array}{l}\text { Bi hizkuntza batera ikasteak ikasketa proze- } \\
\text { sua indartu dezakeela ulertzeko zailtasunak. } \\
\text { Hizkuntza batetik bertzera pasatako ezauga- } \\
\text { rriak akats gisa ikusiak. }\end{array}$ & $\begin{array}{l}\text { Elebidun sortuberriaren baliabide linguisti- } \\
\text { koak lehenbiziko hizkuntzan zein bigarre- } \\
\text { naren ikasketa prozesurako onuragarriak } \\
\text { dira, horrela, hiztunak transferentziak egi- } \\
\text { teko gai izanik. }\end{array}$ \\
\hline $\begin{array}{l}\text { Hizkuntza bakoitzean egindako ekoizpena } \\
\text { banatuta ebaluatzen da eta, beraz, ikuspegi } \\
\text { mugatua hartzen da. }\end{array}$ & $\begin{array}{l}\text { Testuak hizkuntzen arteko konparaketa bi- } \\
\text { dez aztertu eta lehenbiziko hizkuntzan zein } \\
\text { helburu hizkuntzan ebaluatzen dira. }\end{array}$ \\
\hline $\begin{array}{l}\text { Ebaluatze-instrumentuak ingelesetik helbu- } \\
\text { ru-hizkuntzara itzulitakoak izan ohi dira. }\end{array}$ & $\begin{array}{l}\text { Hizkuntza bakoitzaren bereizgarri diren ezau- } \\
\text { garri linguistiko zein diskurtsiboak kontuan } \\
\text { hartzen dira ebaluatzeko orduan. }\end{array}$ \\
\hline $\begin{array}{l}\text { Elebidunek bi hizkuntzetan egindako ariketa } \\
\text { linguistiko guztietan maila linguistiko berdina } \\
\text { izanen dutela espero da. }\end{array}$ & $\begin{array}{l}\text { Elebidunak hizkuntza-gaitasun ona izan de- } \\
\text { zake edozein motako ariketa-sorta zein edo- } \\
\text { zein hizkuntzatan. }\end{array}$ \\
\hline $\begin{array}{l}\text { Elebidunek erabilitako estrategia linguisti- } \\
\text { koak bi hizkuntzetan gaitasun baxua izatea- } \\
\text { ren erakusgarri dira. }\end{array}$ & $\begin{array}{l}\text { Ikasle elebidunak idatzizko ekoizpenean era- } \\
\text { bilitako idatzizko estrategia elebidunak ikas- } \\
\text { prozesuaren parte ikusten dira. }\end{array}$ \\
\hline $\begin{array}{l}\mathrm{H} 2 \mathrm{n} \text { idatzizko gaitasunaren ikasketa prozesua } \\
\text { elebakarren idatzizko ekoizpena ebaluatzeko } \\
\text { diseinatutako tresnen bidez aztertzen da. }\end{array}$ & $\begin{array}{l}\text { H2n idatzizko gaitasunaren ikasketa-proze- } \\
\text { sua elebidunentzat diseinaturiko tresnen bi- } \\
\text { dez neurtzen da. }\end{array}$ \\
\hline
\end{tabular}


Laburbilduz, idatziaren ebaluazioa egitean ere, hiztun eleaniztuna eta horren ekoizpena bere osotasunean aztertzeko beharra azpimarratzen da. Horretarako, hizkuntzen arteko elkarreragina ulertu eta kontuan hartu behar da, baita ebaluazio holistikorako diseinaturiko tresnak erabili ere. Ebaluazio-neurri holistiko hauetan sailkatzen den errubrika erabili da, hain zuzen ere, lan honetarako: ESL Profile (Jacobs eta bertze, 1981). Lan honetarako erabili den metodologia zehazten duen atalean deskribatuko da errubrika hori.

Horrekin guztiarekin, hizkuntza bat baino gehiagoren jabekuntza-prozesua $\mathrm{H} 2 \mathrm{n}$ jabekuntza baino prozesu konplexuagoa dela erran daiteke, baita bere-bereak dituen adierazle, elkarreragin eta tasunak dituela ere. Focus on Multilingualism (Cenoz eta Gorter, 2011, 2014) ikuspegiak hiztun eleaniztunaren errepertorio linguistikoa osatzen duten hizkuntza guztiak, beren elkarreragin prozesu konplexuarekin batera, ikuspegi holistiko eta oso baten bidez aztertzea du helburu, baita hizkuntza bakoitzak bertzearen jabekuntza eta garapenean nola eragiten duen aztertzea ere.

Ikerketa honen marko teorikoa aurkeztu ondoren, hurrengo atalean gure helburu nagusia aurkeztu eta hori betetzeko zer-nolako ikerketa-galderak planteatu diren zehaztuko da.

\subsection{Helburua eta ikerketa galderak}

Lan honen helburu nagusia Bigarren Hezkuntzako ikasle eleanitzek ekoitzitako idatzizko testuetan azaleratzen diren hizkuntza elkarreraginak identifikatzea eta aztertzea da. Ikasleek idatzizko ekoizpenak egitean aurrera eramandako prozesu eta estrategia linguistiko konplexuak ulertu nahi dira, beraien errealitatera hobeki egokitzen diren metodologiak diseinatzeko aukerak izateko. Halaber, idatziaren ebaluazioan ere hiztun eleaniztunaren errealitate hori zein bere ekoizpena bere osotasunean eta ikuspegi holistiko batetik lantzeko beharra kontuan hartu nahi izan da. Era berean, ikasleak duen jakintza linguistikoak bere idatzizko ekoizpenetan eta horietan egindako transferentzietan nola eragin dezakeen aztertu nahi da. Hori kontuan izanik, hauexek dira helburu hori betetzeko lan honen oinarri eta zutabe izanen diren ikerketa galderak:

1. Zein hizkuntza transferentzia gauzatzen ditu hiztun eleaniztunak bere errepertorio linguistikoa osatzen duten hizkuntzen artean idatzizko ekoizpenak egiteko orduan?

2. Nola ordenatzen dira estrategia horiek maiztasunaren arabera?

3. Zein da estrategien maiztasuna hiztunak idatzian erraztasun handiena duen hizkuntzaren arabera?

Horrela, bada, ikerketa honetan eleaniztunen ekoizpen idatziak hurbilpen holistiko baten bitartez aztertu nahi izan dira, hau da, ekoizpenak 
aztertzeko lanketa holistiko bat azaldu. Lanketa horretan, ikerketako partaideen errepertorio linguistiko osoa aztertu da. Batetik, idatzizko ekoizpenetan zuzentasun linguistikoa kontuan hartuta, hiztun eleaniztunaren hizkuntzak bata bertzearekin erlazionatuta edo lotuta dauden aztertu da; bertzetik, elkarreragin horretan sakonduz, hizkuntza-transferentziak identifikatu eta motaren arabera sailkatu dira. Halaber, honen inguruan burutu diren orain arteko ikerketa gehienek bi hizkuntza hartu dituzte kontuan (Berman, 1994; Gass eta Selinker, 1983; Sharwood-Smith, 1994). Ikerketa honetan, aldiz, hiru hizkuntza aztertu dira, hiztunen egungo errealitate eleaniztunera eta kulturanitzera egokituz eta errepertorio linguistiko osoa kontuan hartuz.

\section{METODOLOGIA}

\subsection{Ikerketaren testuingurua eta partaideak}

Ikerketa honetarako datuak Nafarroako Foru Komunitateko Bigarren Hezkuntzako Institutu batean jaso dira. 1986ko Euskararen Legeak Nafarroa hiru eremu soziolinguistikotan banatzen du eremu bakoitzeko hiztun euskaldunen arabera: eremu euskalduna, mistoa eta ez-euskalduna. Lege horren arabera, eremu bakoitzean euskal hiztunak eskubide desberdinak izanen ditu. 2016an egindako datu jasoketa baten arabera, Nafarroako populazioaren $\% 12,9 \mathrm{k}$ euskal hiztuna dela adierazi du, \% 10,3k euskaldun pasiboa eta \% 76,7k ez euskal hiztuna. Edonola ere, zenbakiek desberdintasun handiak erakusten dituzte eremu bakoitzaren arabera: eremu euskaldunean \% 61,1 da euskal hiztuna, eremu mistoan \% 11,3 eta eremu ez euskaldunean, \% 2,7. Orotara, 2011tik 2016ra euskal hiztunen kopuruak gora egin du: 2011n \% 11,7 ziren eta 2016an \% 12,9 (Nafarroako Gobernua Euskarabidea, 2017). Ikerketa honetarako egin den datu bilketa eremu euskalduneko ikastetxe batean egin da.

Datuak jaso diren ikastetxean lehen atzerriko hizkuntza gisa ingelesa irakasten da, eta zenbait ikasgaietan CLIL (Content and Language Integrated Learning) metodologia erabiltzen dute, Gorputz Heziketan, kasu. Horrela, bada, gure helburuak betetzeko testuinguru egokia dela ikusirik, ingurune eleaniztun horretan bizi diren ikasleen lagina aukeratu da ikerlan honetarako.

Ikerketa honen lagina osatzen duten partaideak Bigarren Hezkuntzako Institutu bateko 4. mailako 20 ikasle dira. Hiru mutilek (\% 15) eta 17 neskak (\% 85) osatzen dute lagina, denak D eredukoak, hau da, euskara irakats hizkuntza dutenak. Partaideen artean, 17 ikasleren ama-hizkuntza euskara da (\% 85), hots, etxean ikasitako lehenengo hizkuntza euskara da; gainerako hiru ikasleren ama-hizkuntza, euskara eta gaztelania dira (\% 15); hau da, etxean bi hizkuntzak aldi berean ikasi dituzte. 


\subsection{Ikerketa tresnak}

Ikerketa honetarako datuak jasotzeko bi tresna erabili dira: galde-sorta eta euskaraz, gaztelaniaz eta ingelesez egindako idazlanak.

Galde-sortan profil soziolinguistikoari, jakintza linguistikoari zein kontzientzia metalinguistikoari buruzko galderak egin dira. Horrela, partaideen adina, maila, sexua, herria, ama-hizkuntza(k) eta ikasleak dakizkien hizkuntzak zein diren jakin da. Horretaz gain, zortzi galdera ere egin dira: (1) lagun-artean, etxean/familian eta eskolan euskara, gaztelania, ingelesa eta bertze hizkuntzaren bat (ikaslearen esku hori betetzea) zenbat erabiltzen ote duten; (2) ikaslearen ustezko gaitasun linguistikoa euskaraz, gaztelaniaz, ingelesez eta bertze hizkuntza (ikaslearen esku hori betetzea) batean, irakurmenean, entzumenean, idazmenean eta ahozko adierazpenean zein den; (3) idazteko erraztasun handiena zein hizkuntzatan duen; (4) idazteko erraztasun txikiena zein hizkuntzatan duen; (5) idazten ari denean hizkuntza batetik bertzera itzulpenak egiten ote dituen; erantzuna baiezkoa bada, kasua zehaztea eskatzen zaie; (6) ingelesez idazten ari denean eta erabili nahi duen hitza ez dakienean zer estrategia erabiltzen ote duen; (7) ikaslearen ustez euskara eta gaztelania, euskara eta ingelesa, eta gaztelania eta ingelesa gramatikalki antzekoak ote diren; (8) ikaslearen ustez euskara eta gaztelania, euskara eta ingelesa, eta gaztelania eta ingelesa hiztegiaren aldetik antzekoak ote diren. Galde-sorta hori euskaraz egina dago. Ikerketa honen helburuetarako hirugarren (idazteko erraztasun handiena zein hizkuntzatan duen) eta laugarren (idazteko erraztasun txikiena zein hizkuntzatan duen) galderetan emandako erantzunak soilik erabili dira; gainontzeko galderetan jasotako informazioa ez da ikerketa honetan erabili.

Idazlanen helburua parte-hartzaileen euskarazko, gaztelaniazko eta ingelesezko idatzizko gaitasuna aztertzea da, baita hauetan gerta daitezkeen elkarreragin linguistikoak identifikatzea eta aztertzea ere. Horretarako, picture description task deituriko ariketa egitea eskatu zaie ikasleei (ikusi Cenoz eta Gorter, 2011; Orcasitas, 2018). Ariketa horretan, ikasleek irudi bat deskribatu behar dute. Hiru hizkuntzetan ariketaren aurkezpena berdina da: «idatzi 20 bat lerroko testua ondoko irudi hau deskribatuz. Idazteko leku gehiago behar izanez gero, atzeko aldea erabil dezakezu». Aitzitik, testuinguru berean kokatuta baldin badaude ere, irudia desberdina da hizkuntza bakoitzean. Orcasitas-en (2018) arabera, hizkuntza-garapena komunikazio egoera erreal batean neurtzea espero da modu horretako ariketaren bidez.

\subsection{Prozedura}

Aipatu bezala, datuak jasotzeko bi tresna erabili dira: galde-sorta eta idazlanak. Ikastetxearekin harremanetan jarri ondotik, galde-sorta eta inge- 
lesezko testuaren ekoizpenak bildu ziren; segidan, euskarazko testuak jaso ziren eta, azkenik, gaztelaniazkoak. Horrela, ikasle bakoitzak ekoitzitako hiru testu eta galde-sorta bana bildu ziren.

Ikasle bakoitzari kode bat jarri eta testuak Microsoft Word programaren bidez transkribatzea izan zen hurrengo eginkizuna. Hori egin ondotik, testuak aztertzeko neurketa-tresnak diseinatu ziren. Bi errubrika eta taula bat aukeratu ziren azterketa horretarako: ESL Composition Profile (Jacobs eta bertze, 1981), Soltero-González, Escamila eta Hopewell-en (2012) lanetik egokitutako errubrika eta testu-konparaketa bidez jasotako datuak erregistratzeko taula.

1. ESL Composition Profile (Jacobs eta bertze, 1981): neurketatresna hau bigarren hizkuntzaren idatzizko ekoizpenak ebaluatzeko diseinatutako errubrika da. Bortz dimentsio neurtzen ditu: edukia, antolaketa, hiztegia, hizkuntza-erabilera eta hizkuntza-mekanismoak. Dimentsio bakoitzari puntuazio bat jarri eta horiek guztiak batuz puntuazio oso bat ondorioztatzeko diseinatuta dago; puntuazio bakoitzak bere deskribapena du. Hauxe da dimentsio bakoitzean atera daitekeen puntuazio maximoa: edukian 30 puntu, antolaketan 20, hiztegian 20, hizkuntza erabileran 25 eta hizkuntza mekanismoetan 5. Tresna hau testu bakoitzari aplikatu zaio, banan-banan.

2. Soltero-González, Escamila eta Hopewell-en (2012) lanetik egokitutako errubrika: zehazki, autore hauek aurkeztutako errubrika originalaren bigarren zatia erabili da lan honetan. Bigarren zati honetan, hizkuntza-transferentziak identifikatu eta motaren arabera sailkatzen dira. Horrela, sei transferentzia eleaniztun mota banatzen dira, eta mota bakoitzaren barruan azpimotak bereiz daitezke. Aipatu behar da tresna hau ere, aurrekoarekin batera, testu bakoitzari banan-banan aplikatu zaiola. Hona, bada, errubrikaren sailkapena:

- Kode aldaketa - codeswitching

- Bi perpausen artean - intersentential (hizkuntza batean hasi eta bertzean amaitu)

- Perpaus beraren barruan - intrasentential

— « » txertatzea hitz bat bertze hizkuntza batetik jaso dela adierazteko

- Bi edo hiru noranzkoko transferentzia sintaktikoa

- Hizkuntzen arteko transferentzia hitz mailan

- Bi edo hiru noranzkoko transferentzia fonetikoa

- Maileguak

- Jatorrizko hizkuntzara egokitutako maileguak - nativized

- Hizkuntzen arteko transferentzia perpaus mailan

- Hitzez hitzezko itzulpena

- Subjektuaren hutsa 
- Hizkuntzen arteko transferentzia maila diskurtsiboan

- Egitura erretorikoak

- Puntuazioa

\section{- Bertzerik?}

Beharrezkoa deritzogu azterturiko hitza «maileguak» eta «jatorrizko hizkuntzara egokitutako maileguak - nativized» gisa sailkatzeko erabilitako irizpideak zein diren argitzeari. Hitz bat mailegu bat den edo ez erabakitzeko, hitzaren jatorriari begiratu zaio: hizkuntza horretan erabilitako hitza bertze hizkuntza batetik badator, mailegutzat hartu da. Horrela, «relax» gaztelaniazko testuetan mailegu gisa identifikatu da, gaztelaniara ingelesetik etorritako hitza baita, nahiz eta hitzaren jatorri etimologikoa latinean egon (relaxare); era berean sailkatu da «beige» euskarazko testuetan, berez frantsesezko hitza dena (beige). Halaber, «jatorrizko hizkuntzara egokitutako maileguak - nativized» sailkatzeko hitzaren jatorria hartu da irizpidetzat. Kasu horretan, ordea, formari dagokionez erabilia den hizkuntzara egokitutako hitzak dira: «taktil» euskaraz erabiltzea, etimologikoki jatorri latindarra duen hitza (tactīlis), edo «alfonbra» euskaraz erabiltzea, jatorri arabiarra duena (alhánbal), kasu (Real Academia Española, 2001). Edonola ere, azken bi hitz horiek euskarara gaztelaniatik etorri direla pentsa liteke, hau da, táctil > taktil eta alfombra > alfonbra.

3. Testu-konparaketa bidez jasotako antzekotasunak sailkatzeko taula: taula horretan lau dimentsio aztertzen dira: lokailuak, testuen egitura orokorra, edukia eta aditza (pertsona eta denbora). Ikasle bakoitzaren hiru testuak elkarren ondoan aztertuz ondoriozta daitezkeen datuak jasotzeko diseinatuta dagoenez, aipaturiko dimentsio bakoitza hiru hizkuntzetan modu berean gauzatzen ote den biltzea da horren helburua. Dena den, taula horretan jaso diren datuak emaitzen interpretaziorako eta ondorioak zehazteko lagungarriak izan badira ere, ez dira emaitzen atalean islaturik agertuko.

Lehengo bi errubriken datuak, hots, ESL Composition Profile (Jacobs eta bertze, 1981) errubrikako datuak zein Soltero-González, Escamila eta Hopewell-enetik (2012) egokitutakoan jasotakoak SPSS (Statistical Package for the Social Sciences) programaren bidez aztertu dira. Programa hori bera erabili da galde-sortaren bidez jasotako datuak ere aztertzeko. Hirugarren taularen bidez jasotako datuak, ordea, eskuz aztertu dira.

\section{EMAITZAK}

Lan honen helburu nagusia da Bigarren Hezkuntzako ikasle eleaniztun batzuek ekoitzitako idatzizko testuetan azaleratzen diren hizkuntza elkarreraginak identifikatzea eta aztertzea. Horretarako, hiru ikerketa-galdera egin dira eta horiek erantzuteko beharrezko diren datuak bildu eta aztertu egin 
dira. Jarraian, honela adieraziko dira datu hauek emandako emaitzak, hots, mahai gainera ekarririko hiru galderaren arabera.

\subsection{Zein hizkuntza-transferentzia gauzatzen ditu hiztun eleanitzak bere errepertorio linguistikoa osatzen duten hizkuntzen artean idatzizko ekoizpenak egiteko orduan?}

Galdera hori erantzuteko bi atal osatu dira: lehenik, ESL Composition Profile (Jacobs eta bertze, 1981) errubrikaren bidez jasotako datuen ebaluazio holistikoa eta, bigarrenik, Soltero-González, Escamila eta Hopewell-en (2012) lanetik egokitutako errubrikaren bidez jasotako datuen transferentzia moten azterketa.

\subsubsection{Testuen ebaluazio holistikoa: euskara, gaztelania eta ingelesa}

Idatzizko ekoizpenen ebaluazioan, hiru hizkuntzak bata bertzearekin erlazionatuta edo lotuta dauden aztertu nahi izan da. Horretarako, ESL Composition Profile (Jacobs eta bertze, 1981) neurketa-tresna holistikoa erabili da. Aipatu den moduan, errubrika horrek hizkuntzaren bortz dimentsiori begiratzen die eta guztien baturaz puntuazio oso bat osatu. Dimentsio bakoitzean atera daitekeen puntuazio maximoa ondorengoa da: edukian 30 puntu, antolaketan 20, hiztegian 20, hizkuntza-erabileran 25 eta hizkuntza-mekanismoetan 5. Era berean, puntuazio bakoitza azaltzeko baliagarriak diren irizpideak ere deskribatzen dira. Deskribapen horiek ondoren ikusiko diren emaitzak azaltzeko erabiliko dira.

Jarraian, ikasleek hizkuntza bakoitzean eskuratutako puntuazioen batezbertzekoak (BB) eta desbideratze estandarra (DE) aurkezten dira.

2. taula

Euskara, gaztelania eta ingelesaren ebaluazio holistikoa

\begin{tabular}{lrrrrrr}
\hline & \multicolumn{2}{c}{ Euskara } & \multicolumn{2}{c}{ Gaztelania } & \multicolumn{2}{c}{ Ingelesa } \\
\cline { 2 - 7 } & \multicolumn{1}{c}{$\mathrm{BB}$} & \multicolumn{1}{c}{$\mathrm{DE}$} & \multicolumn{1}{c}{$\mathrm{BB}$} & \multicolumn{1}{c}{$\mathrm{DE}$} & \multicolumn{1}{c}{$\mathrm{BB}$} & $\mathrm{DE}$ \\
\hline Edukia & 25,05 & 2,212 & 25,00 & 2,449 & 24,90 & 2,594 \\
Antolaketa & 16,85 & 1,348 & 17,25 & 0,967 & 16,35 & 1,725 \\
Hiztegia & 17,05 & 0,945 & 17,55 & 0,887 & 16,30 & 1,838 \\
Hizkuntza erabilera & 20,10 & 1,334 & 20,80 & 1,361 & 19,70 & 1,949 \\
Hizkuntza mekanismoak & 4,40 & 0,503 & 4,50 & 0,531 & 4,10 & 0,553 \\
\hline Guztira & 83,45 & 4,334 & 85,10 & 5,241 & 81,35 & 7,862 \\
\hline
\end{tabular}


Ikus daitekeen moduan, puntuazioari guztira erreparatuz gero ikasleek gaztelaniaz izan dute puntuaziorik altuena $(B B=85,10 ; D E=5.241)$. Euskaraz dute hurrengo puntuaziorik altuena $(B B=83,45 ; D E=4,334)$, ingelesak jarraiturik $(\mathrm{BB}=81,35 ; \mathrm{DE}=7.862)$. Dimentsioak banan-banan aztertuz, gaztelaniazko puntuazioan dute batezbertzekorik altuena bai antolaketan $(\mathrm{BB}=17,25$; $\mathrm{DE}=0,967)$, bai hiztegian $(\mathrm{BB}=17,55$; $\mathrm{DE}=0,887)$, bai hizkuntza-erabileran $(\mathrm{BB}=20,80 ; \mathrm{DE}=1,361)$ eta bai hizkuntza-mekanismoetan $(\mathrm{BB}=4,50 ; \mathrm{DE}=0,531)$; edukian, ordea, euskarazko testuetan dute puntuaziorik altuena $(\mathrm{BB}=25,05 ; \mathrm{DE}=2,212)$.

Era berean, hiru hizkuntzatako puntuazio holistiko horiek elkarren artean loturarik duten aztertu da. Horretarako, ESL Composition Profile (Jacobs eta bertze, 1981) errubrikan neurtutako hizkuntzaren bortz dimentsioetan aldagaien arteko azterketa korrelazionala (Pearson) egin da.

\section{3. taula}

\section{Euskara, gaztelania eta ingelesaren puntuazioen arteko korrelazioa}

\begin{tabular}{lccc}
\hline & Euskara/Gaztelania & Euskara/Ingelesa & Gaztelenia/Ingelesa \\
\hline Edukia &, $447^{*}$ &, 139 &, 356 \\
Antolaketa &,- 050 &, 386 &, 260 \\
Hiztegia &,- 223 &,- 009 &, 378 \\
Hizkuntza erabilera &, 128 &, $640^{* *}$ &, 194 \\
Hizkuntza mekanismoak &,- 204 &, 227 &, 371 \\
\hline Guztira &, 348 &, 431 &, $455^{*}$ \\
\hline
\end{tabular}

*. Korrelazioa adierazgarria da 0,05 mailan (aldebikoa).

**. Korrelazioa adierazgarria da 0,01 mailan (aldebikoa).

Euskara eta gaztelaniari dagokienez, hizkuntza bakoitzean edukian jasotako emaitzek dute erlazio korrelazional adierazgarria. ESL Composition Profile (Jacobs eta bertze, 1981) errubrikara joz gero, horrekin zera erran nahi da: bi hizkuntzetan gaiaren inguruko zenbait jakintza agertu, maila egokia erakutsi, tesiaren garapen mugatua gauzatu eta, oro har, edukiarekin lotutako gaia landu baina zehaztapen gutxirekin garatu izanak lotura esanguratsua duela.

Euskara eta ingelesaren artean, hizkuntza erabileran dago lotura adierazgarria. Horrekin, bai euskaran eta bai ingelesean egitura eraginkorrak baina sinpleak erabili dituztela, egitura konplexuen erabileran arazo gutxi izan dituztela, testuaren ulergarritasuna inoiz edo behin eragotzia izan dela, aditz-komunztaduran, denboran, zenbakian, hitz ordenan/funtzioan, artikuluetan, izenordainetan eta preposizioen erabileran akats batzuk egin dituztela eta garatu gabeko edo gaizki garatutako zenbait esaldi erabili izatea esanguratsua dela erran nahi da (Jacobs eta bertze, 1981). 
Azkenik, gaztelania eta ingelesari dagokienez, dimentsioka aztertuz gero lotura adierazgarririk ikusten ez badugu ere, aipatzekoa da azterketa holistikoa edo bateratua eginda puntuazio osoaren emaitzek korrelazio adierazgarria dutela.

Laburbilduz, azterketa korrelazionalak erraten digunaren arabera, aztertutako testuetan erabilitako hizkuntza guztien artean aurkitu daiteke dimentsioren bat lotura esanguratsua duena, hots, zoriari zor ez zaiona: euskara eta gaztelaniazko ekoizpenetan ikasleek edukian jaso duten puntuazioek dute lotura esanguratsua; era berean, euskara eta ingelesari dagokienez, hizkuntza erabileran jaso duten emaitza da korrelazionala dena; eta gaztelania eta ingelesari dagokienez, berriz, puntuazio osoan jaso duten emaitza da zoriari zor ez zaiona.

\subsubsection{Transferentzia motak}

Bigarren atal honetan, ikerlan honetako partaideek beren hiru hizkuntzetako ekoizpenetan erabili dituzten transferentziak zein diren aztertuko da, baita transferentzia horiek zenbat ikaslek gauzatu dituzten ere. Hiru hizkuntzei dagozkien datuak elkarturik aurkeztuko dira ondorengo taulan. Errubrikan jasotako transferentzia mota batzuk ez dira inongo testutan agertu; transferentzia horiek, $O$ zenbakiaren bidez islatu dira. Hona hemen transferentzia mota zein hori gauzatu duten ikasle kopurua adierazten duen taula:

4. taula

\section{Transferentzia motak euskaraz, gaztelaniaz eta ingelesez eta haiek gauzatu dituzten ikasle kopurua}

\begin{tabular}{lccc}
\hline & $\begin{array}{c}\text { EUSKARA } \\
\text { Ikasle kopurua }\end{array}$ & $\begin{array}{c}\text { GAZTELANIA } \\
\text { Ikasle kopurua }\end{array}$ & $\begin{array}{c}\text { INGELESA } \\
\text { Ikasle kopurua }\end{array}$ \\
\hline Kode aldaketa: intersentential & 0 & 0 & 0 \\
Kode aldaketa: intrasentential & 0 & 0 & 8 \\
«» txertatzea & 3 & 0 & 4 \\
Transferentzia sintaktikoa & 8 & 0 & 10 \\
Transferentzia fonetikoa & 0 & 0 & 7 \\
Mailegua & 2 & 2 & 0 \\
Jatorrizko hizkuntzara egokitutako & 17 & 2 & 6 \\
maileguen erabilera & 7 & 1 & 18 \\
Hitzez hitzezko itzulpena & 0 & 0 & 4 \\
Subjektuaren hutsa & 0 & 0 & 0 \\
Egitura erretorikoak & 0 & 0 & 0 \\
Puntuazioa & 1 & 1 & 3 \\
Bertzerik & 38 & 6 & 60 \\
\hline Guztira & & &
\end{tabular}


Euskarazko testuetan errubrikaren bidez bilaturiko hamabi transferentzia motetatik sei identifikatu dira: euskarara egokitutako maileguen erabilera $(n=17)$, transferentzia sintaktikoa $(n=8)$, hitzez hitzezko itzulpenak $(n=7)$, «» txertatzea $(n=3)$, maileguen erabilera $(n=2)$, eta errubrikan bertzerik gisara definiturikoak, kasu honetan euskarari ez dagozkion elementu ortotipografikoen erabilera $(n=1)$.

Halaber, transferentziak gauzatu dituzten ikasle kopurua aztertuz gero, ikasle gehienek egin duten transferentzia mota euskarara egokitutako maileguen erabilera izan da (telefono mugikor, ordenagailu, tablet, liburu elektronikoa, taktil, alfonbra, grix, xinplea, moderno), 20tik 17 ikaslek, hain zuzen ere. Gainerakoekin alderatuz, ikasleen artean nabarmenki zabalduena da. Aitzitik, ikasleen artean gutxien errepikaturikoa euskarari ez dagozkion elementu ortotipografikoak erabiltzea izan da.

Sei transferentzia mota horietatik bi perpaus mailakoak dira: transferentzia sintaktikoa (Barregarri zaigu < se nos hace gracioso / cómico, argazki honek familia polit bat ikusten eginarazten digu < esta imagen nos hace ver una bonita familia) eta hitzez hitzezko itzulpena (ongi eramaten direla dirudi $<p a-$ rece que se llevan bien, ongi pasatzeko intentzio bakarrarekin $<$ con la única intención de pasárselo bien, nahikoa dute hitz egitearekin < les basta con hablar / les es suficiente con hablar, modu animatuan» < de un modo animado ); gainerako laurak, berriz, hitz mailakoak, maileguen erabilera (beige), kasu.

Gaztelaniazko testuetan errubrikan kontuan harturiko 12 transferentzia motetatik lau transferentzia mota identifikatu dira: maileguen erabilera $(n=2)$, gaztelaniara egokitutako maileguen erabilera $(n=2)$, hitzez hitzezko itzulpena $(n=1)$, eta bertzirik gisara sailkatua, hots, gaztelaniari ez dagozkion elementu ortotipografikoen erabilera $(n=1)$.

Hala ere, hauek gauzatu dituzten ikasle kopurua murritz samarra da: gehienez ere, bi ikaslek erabili dituzte maileguak edo gaztelaniara egokitutako maileguak.

Lau transferentzia mota horietatik hiru hitz mailakoak dira (\% 75): maileguen erabilera (crack, relax), gaztelaniara egokitutako maileguen erabilera (fútbol) eta gaztelaniari ez dagozkion elementu ortotipografikoen erabilera (espazioso, partxis). Hitzez hitzezko itzulpena (una grande mesa), ordea, perpaus mailakoa da (\% 25).

Ingelesezko testuetan errubrikan jasotako hamabi motetatik zortzi transferentzia mota gauzatu dira: hitzez hitzezko itzulpena $(n=18)$, transferentzia sintaktikoa $(n=10)$, kode aldaketa intrasententziala $(n=8)$, transferentzia fonetikoa $(n=7)$, ingelesera egokitutako maileguen erabilera $(n=6)$, «txertatzea» $(n=4)$, subjektuaren hutsa $(n=4)$ eta bertzerik modura sailkatuak, kasu honetan hutsunea utzi edo idatzitako hitzaren ondoan () artean gaztelaniazko itzulpena ematea $(n=3)$.

Ikasle gehienek egindakoa hitzez hitzezko itzulpena izan da, 20tik 18k egin baitute (It has a air of now a day < tiene un aire de hoy en día, they have an order about the things and objects < tienen un orden sobre las cosas). 
Orobat, partaideen erdiak transferentzia sintaktikoa gauzatu du (the shine of the sun < el brillo del sol). Ikasleen artean gutxien zabaldua hutsunea uztea edo ondoan gaztelaniazko adiera ematea izan da, hiru ikaslek egina (there are many lamps (lampara), parentesien erabilera aurreko hitza argitzeko).

Zortzi transferentzietatik lau perpaus mailakoak dira (\% 50): kode aldaketa intrasententziala (In the (armario) there are books (...) the girl has $a$ (coleta) and (...) the boy wears a t shirt with - rayas-), transferentzia sintaktikoa, hitzez hitzezko itzulpena eta subjektuaren hutsa (Is a really big dining room). Bertze erdia (\%50), hitz mailakoa.

Horrela, bada, 4. taulan ondorengo datu horiei erreparatzeari interesgarri deritzogu: lehenik, ikasle kopuruari erreparatuz, ikasle gehienek egin duten transferentzia mota ingelesezko ekoizpenetan gauzatu da (hitzez hitzezko itzulpena, $-\mathrm{n}=18-$ ). Bigarrenik, transferentzia motari begiraturik, berriz, transferentzia mota gehien ingelesezko testuetan identifikatu dira, errubrikan jasotako hamabi motetatik zortzi, hain zuzen ere. Aitzitik, transferentzia mota gutxien gaztelaniazko testuetan aztertu dira, errubrikako 12 motetatik lau; identifikaturiko lau transferentzia mota horiek, gainera, ikasle gutxik gauzatu dituzte. Hirugarrenik, hizkuntza bakar batean ere identifikatu ez diren transferentziak daude erabilitako errubrikan.

\subsection{Nola ordenatzen dira estrategia horiek maiztasunaren arabera?}

Aurreko atalean partaideek beren hiru hizkuntzetako ekoizpenetan erabili dituzten transferentziak zein diren aztertu da, baita transferentzia bakoitza zenbat ikaslek erabili duten ere. Jarraian, errubrikaren bidez identifikaturiko transferentziak maiztasunaren arabera ordenatuko dira, hots, transferentzia bakoitza zenbat aldiz erabili den aztertuko da. Corpusa bere osotasunean hartuta landuko da, hau da, hiru hizkuntzetako elkarreragin linguistikoak elkarrekin eta modu holistikoan.

Bosgarren taulan ikus daitekeen moduan, gehien gertatu den transferentzia euskarazko testuetan eman da. Transferentzia hori hitz mailakoa da: euskarara egokitutako maileguen erabilera eta guztira, 62 aldiz gertatu da. Hurrengo transferentzia 38 aldiz gauzatu da eta ingelesezko testuetan gertatu da: hitzez. hitzezko itzulpena. Hori, perpaus mailako transferentzia mota da. Horren ondotik, ingelesezko testuetan perpaus beraren barruan kode aldaketa gertatu da gehien, 15 aldiz, hain justu ere. Hemendik aurrerako sei transferentzia motak, 10-14 bitarte alditan eman dira, guztiak euskarazko testuetan edo ingelesezko testuetan gauzatuak. Hurrengo bi transferentzia motak ingelesezko testuetan gauzatu dira: batetik, subjektuaren hutsa gauzatzea, guztira sei aldiz gertatua, eta, bertzetik, errubrikan «bertzerik» gisara sailkaturikoak, guztira hiru aldiz gertatuak. Hurrengo hiru transferentzia motak, berriz, euskarazko testuetan gauzatu dira, hiru aldiz edo bi aldiz gertatuak, hurrenez hurren. Azkeneko lau tokietan gaztelaniazko ekoizpenetan gertatutako transferentziak aurkitu daitezke, gutxien gertatutakoak horiek baitira. 
5. taula

Euskara, gaztelania eta ingelesezko transferentziak eta haien maiztasuna

\begin{tabular}{lc}
\hline \multicolumn{1}{c}{ Transferentzia mota } & Maiztasuna \\
\hline Euskara: euskarara egokitutako maileguen erabilera & 62 \\
Ingelesa: Hitzez hitzezko itzulpena & 38 \\
Ingelesa: Kode-aldaketa: intrasentential & 15 \\
Ingelesa: Transferentzia sintaktikoa & 14 \\
Euskara: Transferentzia sintaktikoa & 13 \\
Ingelesa: Transferentzia fonetikoa & 12 \\
Euskara: Hitzez hitzezko itzulpena & 12 \\
Ingelesa: «» txertatzea & 11 \\
Ingelesa: Jatorrizko hizkuntzara egokitutako maileguak & 10 \\
Ingelesa: Subjektuaren hutsa & 6 \\
Ingelesa: Bertzerik? & 3 \\
Euskara: «» txertatzea & 3 \\
Euskara: Mailegua & 2 \\
Euskara: Bertzerik: Euskarari ez dagozkion elementu ortoti- & 2 \\
pografikoen erabilera & 2 \\
Gaztelania: Mailegua & 2 \\
Gaztelania: Bertzerik: Gaztelaniari ez dagozkion elementu & 2 \\
ortotipografikoen erabilera & 1 \\
Gaztelania: Hitzez hitzezko itzulpena & 1 \\
Gaztelania: Jatorrizko hizkuntzara egokitutako maileguen & \\
erabilera & \\
\hline
\end{tabular}

Hala bada, ondorengo datu hauei erreparatzeari interesgarri deritzogu: lehenik, gehien gertatutako transferentzia euskaraz gertatutakoa da, eta ingelesez egindakoak bigarren eta hirugarrenak, beraien arteko kopuruaren arteko ezberdintasunak nabarmenak izanik; bigarrenik, orokorrean, eta nabarmenki gainera, euskarazko eta ingelesezko ekoizpenetan gertatutako transferentziak dira gehien gauzatu direnak; hirugarrenik eta azkenik, gaztelaniaz gertatuak oso urriak dira.

\subsection{Zein da estrategien maiztasuna hiztunak idatzian erraztasun handiena duen hizkuntzaren arabera?}

Galdera horrekin ikasleak bere idazteko gaitasunarekiko duen autopertzepzioak berak gauzatzen dituen transferentzietan eraginik ote duen aztertu nahi izan da. Halaber, idazteko erraztasun gehien duen hizkuntza erabiltzen 
ari denean transferentziarik gauzatzen ote duen eta, hala izanez gero, zein transferentzia diren eta zenbat aldiz gauzatzen dituen ere aztertu nahi izan da.

Galdera hori erantzuteko galde-sortan bildutako datuak erabili dira. Galdetegiko galderetako bat ondorengoa izan da: zein hizkuntzatan duzu idazteko erraztasun handiena? Galdera horri ikasleen \% 73,7k idazteko erraztasun handiena euskaraz dutela erantzun diote; gainerako \% 26,7k, berriz, gaztelaniaz errazago idazten duela. Erantzun horien arabera, bi talde osatu dira: idazteko erraztasun handiena euskaraz duten ikasleak $(\% 73,7$, $\mathrm{n}=14)$ eta idazteko erraztasun handiena gaztelaniaz duten ikasleak (\% 26,7, $\mathrm{n}=5$ ). Horrela, bada, talde bakoitzeko partaideek gauzatutako transferentzia linguistikoak maiztasunaren arabera ordenatu dira.

Ondorengo taulan idazteko erraztasun handiena euskaraz duten ikasleek gauzatutako transferentziak sailkatu eta maiztasunaren arabera ordenatuak aurkeztuko dira; horren ondotik, errazen gaztelaniaz idazten duten ikasleen ekoizpen guztietan gertatutako transferentziak, horiek ere sailkatuta eta maiztasunaren arabera ordenatuak.

Lehenik, idazteko erraztasun handiena euskaraz duten ikasleen ekoizpen guztiei erreparatuko zaie.

6. taula

Euskaraz errazago idazten duten ikasleek egindako transferentziak eta haien maiztasuna

\begin{tabular}{lc}
\hline \multicolumn{2}{c}{ Errazen euskaraz idazten duten ikasleak } \\
\hline \multicolumn{1}{c}{ Transferentzia mota } & Maiztasuna \\
\hline Euskara: Euskarara egokitutako maileguen erabilera & 35 \\
Ingelesa: Hitzez hitzezko itzulpena & 32 \\
Ingelesa: Kode aldaketa: intrasentential & 13 \\
Euskara: Transferentzia sintaktikoa & 10 \\
Euskara: hitzez hitzezko itzulpena & 10 \\
Ingelesa: Transferentzia sintaktikoa & 9 \\
Ingelesa: Transferentzia fonetikoa & 9 \\
Ingelesa: Jatorrizko hizkuntzara egokitutako maileguak & 7 \\
Ingelesa: «» txertatzea & 4 \\
Ingelesa: Subjektuaren hutsa & 4 \\
Euskara: Bertzerik & 2 \\
Gaztelania: gaztelaniara hizkuntzara egokitutako maileguen erabilera & 2 \\
Euskara: «» Txertatzea & 1 \\
Ingelesa: Bertzerik? & 1 \\
Gaztelania: Mailegua & 1 \\
Gaztelania: Hitzez hitzezko itzulpena & 1 \\
Gaztelania: Bertzerik? & 1 \\
\hline
\end{tabular}


Guztira, euskarazko, gaztelaniazko zein ingelesezko testuak kontuan harturik, 17 transferentzia mota gauzatu dituzte. Kasu gehienetan gertatu den transferentzia euskarazko testuetan izan da, hitz mailako transferentzia, hain zuzen ere: euskarara egokitutako maileguen erabilera, 35 aldiz gauzatu da. Horren ondotik, ingelesezko testuetan gauzatutakoa dator, kopuru berdintsuarekin, gainera: 32 aldiz gauzatu da hitzez hitzezko itzulpena. Transferentzia mota hori, ordea, perpaus mailakoa da. Lehenbiziko bi horien artean alde nabarmenik ez badago ere, hirugarrena 13 aldiz gertatu da, 19 puntuko distantziara, beraz; ingelesezko testuetan gauzatu den kode aldaketa intrasententziala da hori. Hemendik aurrera gertatu diren bortz transferentziak zazpi eta 10 aldi bitartean gauzatu dira, denak euskarazko eta ingelesezko testuetan. Bortzetik beherako kopuruan guztira bederatzi transferentzia mota ditugu: ingelesezko testuetan gauzatutako «» txertatzea eta subjektuaren hutsa, bakoitza lau aldiz gauzatu da; halaber, bi aldiz gertatuak euskarazko testuetan errubrikan bertzerik gisara sailkatuak eta gaztelaniazko testuetan aztertutako gaztelaniara egokitutako maileguen erabilera dira. Hurrengo bortz transferentziak, bakoitza behin bakarrik identifikatu da, bat euskarazko testuetan, bertze bat ingelesezkoetan eta bertze hiruak gaztelaniaz ekoitzitakoetan.

Horrela, bada, datu horiek aztertzeko orduan honi erreparatzea egoki deritzogu: idazleak errazen euskaraz idazten badu ere, gehien gertatu den transferentzia euskarazko testuetan izan da; ingelesezko testuetan gauzatutako bigarren transferentzia mota ia kopuru berdinean gertatu da, hala ere; aipatutako bi horiek hirugarrenari ateratzen dioten aldea nabarmena da; gutxien gertatutakoak, nabarmenki, gaztelaniaz gertatutakoak dira.

Jarraian, idazteko erraztasun handiena gaztelaniaz duten ikasleen ekoizpenei erreparatuko zaie.

7. taula

\section{Gaztelaniaz errazago idazten duten ikasleek egindako} transferentziak eta haien maiztasuna

\begin{tabular}{lc}
\hline \multicolumn{1}{c}{ Errazen gaztelaniaz idazten duten ikasleak } \\
\hline \multicolumn{1}{c}{ Transferentzia mota } & Maiztasuna \\
\hline Euskara: Euskarara egokitutako maileguen erabilera & 20 \\
Ingelesa: «» txertatzea & 7 \\
Ingelesa: Hitzez hitzezko itzulpena & 5 \\
Ingelesa: Transferentzia sintaktikoa & 5 \\
Euskara: Transferentzia sintaktikoa & 3 \\
Ingelesa: Transferentzia fonetikoa & 3 \\
Ingelesa: ingelesera egokitutako maileguak & 3 \\
Ingelesa: kode aldaketa: intrasentential & 2 \\
Ingelesa: Subjektuaren hutsa & 2 \\
Euskara: hitzez hitzezko itzulpena & 1 \\
Ingelesa: Bertzerik & 1 \\
\hline
\end{tabular}


Ikasleok, guztira, 11 transferentzia mota gauzatu dituzte. Euskarazko ekoizpenetan euskarara egokitutako maileguen erabilera izan da transferentzia mota gauzatuena, 20 aldiz gauzatua. Hitz mailako transferentzia dugu hau, beraz. 13 puntuko aldea ateratzen dio bigarrenari, ingelesezko testuetan gertatutako «» txertatzea; hitz mailako transferentzia hori zazpi aldiz gauzatu da. Azkenera bitarte, hurrengo transferentzia guztiak euskarazko edo ingelesezko testuetan gauzatutakoak izan dira, batetik bortzerako tartean. Azkenekoa, ingelesezko testuan ikusitakoa da, behin gertatua.

Datuak aztertzeko orduan, honako datu hauei erreparatzeari interesgarri deritzogu: gehien gertatutako transferentzia euskarazko testuetan gertatu da; lehenbiziko transferentzia hori nabarmenki desberdintzen da hurrengoetatik; ez da gaztelaniazko testuetan gertatutako transferentziarik identifikatu.

Laburbilduz, datu horiek erakusten dutena ondorengo bi puntu hauetan bil dezakegu: batetik, bi taldeetan gehien gauzaturiko transferentzia euskarazko ekoizpenetan gertatu da, euskarara egokitutako maileguen erabilera, hain justu ere; bertzetik, gaztelaniazko ekoizpenetan gauzatutako transferentziak dira gutxien gertatu direnak: idazteko erraztasun handiena euskaraz duten ikasleen ekoizpenetan, gaztelaniazko ekoizpenetan lau transferentzia mota gertatu direla ikusi da; transferentzia horietatik bat, bi aldiz gertatu da; bertze hirurak, behin. Idazteko erraztasun handiena gaztelaniaz duten ikasleen ekoizpenetan, berriz, ez da gaztelaniazko transferentzia motarik identifikatu.

\section{EZTABAIDA}

Hiztun eleaniztuna hizkuntza ezberdinei dagozkien eta bere hizkuntza errepertorioa osatzen duten hainbat elementu linguistikoren jabe da, horrela, hiztunaren jardun linguistikoak bere-bereak dituen adierazle, elkarreragin eta tasunak dituela (Cenoz eta Gorter, 2011, 2014). Elementu linguistiko horiek etengabeko elkarreragin konplexuan egonik, hizkuntza-elkarreraginak gerta daitezke hiztunaren ekoizpenetan, hizkuntzaren dimentsio ezberdinetan, gainera. Lan honetan, hizkuntza-elkarreragin horiek ikuspegi holistiko baten bidez aztertu nahi izan dira. Horretarako, ondorengo ikerketa galdera hauek erantzun dira: (1) zein hizkuntza transferentzia gauzatzen ditu hiztun eleaniztunak bere errepertorio linguistikoa osatzen duten hizkuntzen artean idatzizko ekoizpenak egiteko orduan?; (2) nola ordenatzen dira transferentzia horiek maiztasunaren arabera?; (3) zein da estrategien maiztasuna hiztunak idatzian erraztasun handiena duen hizkuntzaren arabera? Ikuspegi holistiko hori erabilita atera diren ondorioak zehaztuko dira jarraian, baita lan honek dituen inplikazio pedagogikoak eta hemendik aurrerako ildoak ere. Segidan, lan honen mugak aipatuko dira eta, azkenik, ikerketa hobetzeko ideiak proposatuko dira. 


\subsection{Ondorioak}

Ikasleek ebaluazio holistikoan jasotako puntuazioari dagokionez, gaztelaniaz izan dute puntuaziorik altuena, hizkuntzaren puntuazio osoan. Ikasleak D eredukoak diren arren eta ikasleen \% 85en ama-hizkuntza euskara den arren, gaztelanian gaitasun hobea erakutsi dute, beraz (ikusi baita ere Orcasitas, 2018). Euskaraz dute hurrengo puntuaziorik altuena, eta ingelesa atzetik doakio. Horrela, bada, gaztelaniaz guztira lortu duten batezbesteko aritmetikoaren puntuazioa 85,10 da, euskaraz 83,45 eta ingelesez 81,35 . Dena den, azpimarratzekoa da ikasleek beren buruarekiko duten pertzepzioa desberdina dela; izan ere, ikasleen \% 73,7k idazteko erraztasun handiena euskaraz dutela uste du, eta gainerako \% 26,7k soilik adierazi du gaztelaniaz errazago idazten duela. Hori ikusirik, beraz, puntuazio altuena euskaraz jasotzea esperoko genuke, eta ez gure ebaluazio holistikoan bildutako puntuazioak.

ESL Composition Profile (Jacobs eta bertze, 1981) errubrikan neurtutako dimentsioetara joz, ikasleek hiru hizkuntzetan jasotako puntuaketen artean edukian jaso duten puntuazioetan dago diferentziarik txikiena. $\mathrm{Fe}-$ nomeno hori edukia dimentsioaren zeharkako izaerari (transversal nature) lotuta dagoela erran daiteke; izan ere, edukiaren inguruko jakintza hizkuntzen artean transferi daitekeen jakintzatzat hartzen da (Orcasitas, 2018). Aitzitik, hizkuntza erabilera eta hiztegia, hala nola hizkuntza bakoitzaren berariazko ezaugarria da (ikusi Arocena, 2017). Orcasitas-ek (2018) dioen bezala, «(these) have been considered more language-specific in nature as they, in fact, measure the accurate use of each specific language» (Orcasitas, 2018: 157. or.). Edonola ere, ikerketa honetako datuen analisi korrelazionalak zera erraten digu: euskaran eta ingelesean hizkuntza erabileraren dimentsioan jasotako puntuazioen arteko lotura da adierazgarri dena. Nahiz eta, ikusi dugun moduan, hizkuntza erabilera berariazko ezaugarritzat har daitekeen, datu hauek irakurriz hizkuntza baten erabilera bertze hizkuntza baten erabilerarekin positiboki lotuta dagoela pentsa liteke. Horrekin zera erran nahi da: hizkuntza bat zenbat eta hobekiago erabili, orduan eta hobekiago erabiliko da bertzea ere. Euskaran eta gaztelanian, berriz, edukiaren dimentsioan jasotako puntuazioen arteko lotura da esanguratsua. Azkenik, gaztelanian eta ingelesean adierazgarria dena ikasleak guztira jasotako puntuazioa da. Horrela, bada, nabarmentzekoa da hiztunak erabilitako hizkuntza guztien artean aurkitu dela lotura esanguratsuren bat, lotura hauek dimentsio ezberdinetan agertu badira ere. Marko teorikoan aipatu bezala, antzekotasun tipologikoa edo distantzia linguistikoa hizkuntzen arteko elkarreraginaren faktore eragileetako bat izan liteke (De Angelis, 2007; Forsyth, 2014). Era berean, hirugarren hizkuntzaren jabekuntza prozesua azaltzen duen Typological Primacy Model (Rothman, 2010, 2011, 2013, 2015) ereduak ere hirugarren hizkuntzan ager daitezkeen transferentziak tipologikoki hurbilen dauden hizkuntzatik jasotzen direla defendatzen du eta, beraz, gure emaitzek bat eginen lukete horrekin. 
Transferentzia horretan sakontzeko asmoz, transferentzia mota zehatzak aztertu dira. Transferentzia mota gehien ingelesezko testuetan identifikatu dira (8 mota), gero euskarazkoetan (6 mota) eta, azkenik, gaztelaniazko ekoizpenetan (4 mota). Ikasle kopuruari dagokionez, ikasle gehienek egin duten transferentzia (hitzez hitzezko itzulpena) ingelesezko ekoizpenetan gauzatu da (18 ikaslek). Hala ere, euskarazko ekoizpenetan euskarara egokitutako maileguen erabilera ikasle kopuru berdintsuak gauzatu du (17 ikaslek). Marko teorikoan aipaturiko De Angelis-en (2007) sailkapenean oinarriturik, lan honetan hizkuntzaren lexikoan, sintaxian eta fonetika eta fonologian (lan honetan hitz mailako transferentziatzat kontuan hartuak) gertatu diren elkarreragin linguistikoak identifikatu dira. Perpaus mailako transferentzia gehien (\% 50) ingelesezko testuetan identifikatu dira; euskara eta gaztelaniazko testuetan azaleratutako transferentzia gehienak, ordea, hitz mailakoak dira (euskaraz \% 66,7, gaztelaniaz \% 75).

Transferentzien maiztasunari dagokionez, gehien errepikatu den transferentzia euskarazko testuetan gauzatu da (euskarara egokitutako maileguen erabilera, 62 aldiz). Horrela, bada, ingelesezko testuetan mota gehiago agertu badira ere, gehien gauzatutako transferentzia (euskarara egokitutako maileguen erabilera) euskaraz idaztean gertatu da. Ordea, gaztelaniazko transferentziak oso gutxitan gauzatu dira, gehien gauzatu dena (maileguen erabilera) 2 aldiz gertatu baita.

Horrela, bada, ikasle hauek eskuarki hizkuntza-elkarreragin gehien euskaraz aritu direnean jaso dituztela erran daiteke; kontuan hartu behar da partaideen \% 85en ama-hizkuntza euskara dela, hain justu ere, edo, beraien autopertzepzioaren arabera, partaideen \% 73,3k errazen euskaraz idazten duela. Edonola ere, ESL Composition Profile (Jacobs eta bertze, 1981) errubrikaren bidez jasotako puntuazioetan, gaztelaniaz batez bertzeko puntuazio altuagoa jaso dute euskaraz baino. Puntuazio baxuena ingelesean jaso dute, hots, hizkuntza gaitasunik baxuena ingelesean erakutsi dute. Hala ere, gaitasun baxuena ingelesean agertu badute ere, aipatu moduan hizkuntza elkarreragin gehien euskaraz aritutakoan gauzatu dituzte. Aitzitik, gaztelaniaren nagusitasuna azpimarratuz, puntuaziorik altuena gaztelanian jaso dute eta, orobat, hizkuntza elkarreraginen arrastorik urrien hemen agertu dira. Horrekin batera, ikasleek beren buruarekiko duten pertzepzioari berriro helduz, aipatzekoa da gaztelaniaz idazteko euskaraz idazteko baino erraztasun txikiagoa dutela adierazi dutela.

Datuok eleaniztasunaren inguruan dugun ikuspegi holistikoarekin bat egiten dutela erran genezake. Izan ere, emaitzek hizkuntzen arteko loturak gauzatzea eleaniztunen baliabide nabarmen eta garrantzitsu bat dela erakusten dute, ikasleek hizkuntza-elkarreragina agertzen baitute beraientzat errazena den hizkuntza batean ere. Cenoz eta Gorter-en (2011) hitzak lerrotara ekarriz, «multilingual individuals are not three or four different people with different strategies in each of their languages; rather, they are speakers who use their resources when communicating with monolingual and 
multilingual interlocutors» (Cenoz eta Gorter, 2011, 367. or). Beraz, hiru hizkuntzen arteko elkarreraginaren azterketaren ondorio gisa, ikasle eleaniztunentzat hizkuntzen arteko elkarreragina estrategia linguistiko eleanitz bat dela uler daiteke. Ortegak (2019) dioen moduan, «language interactions and crosslinguistic influence are part of the broader reality of bilingualism, and neither phenomenon can be viewed as a sign of lesser competence in the L2 that will slowly but surely disappear with sufficient proficiency» (Ortega, 2019, 25. or).

Azkenik, ikerketa honek ekarpen edo berritasunak ere aurkeztu dituela erran daiteke: alor horretan egin diren ikerketa gehienek bi hizkuntza hartu izan dituzte kontuan; honetan, aldiz, hiru hizkuntzen azterketa bateratua izan da helburu. Horri loturik, hurbilpen elebakarra alde batera utzi eta elaniztunen ekoizpen idatzien azterketa holistiko baten lanketa-eredu bat ekarri da, zehazki, «Focus on Multilingualism» ikuspegi eleaniztunarena (Cenoz eta Gorter, 2011, 2014).

\subsection{Inplikazio pedagogikoak eta etorkizunerako ildoak}

Ikerketa honetako datu eta emaitzek hizkuntza-irakasleek kontuan hartu beharreko inplikazio pedagogikoak dituztela erran daiteke; izan ere, hiztun eleaniztunak idatzizko ekoizpenak sortzeko orduan burutzen duen prozesu konplexua hobeki ulertu eta azaltzeko lagungarri izan daitezke. Ikasleek ekoizpenak egitean erabiltzen dituzten estrategia linguistikoak ulertzeak, ikasleen errealitatera hobeki egokitzen diren idatziaren irakaskuntza-metodo eraginkorragoak diseinatzeko aukera ekarriko luke. Horrela, ikasleak idatzizko estrategia zabalagoak eta garatuagoak jorratzeko aukera izanen luke. Era berean, idatziaren ebaluazioan hiztun eleaniztuna eta haren ekoizpena osotasunean aztertzearen beharrari erantzuten dio, ebaluazio holistikorako diseinaturiko tresnak erabiliz eta hizkuntzen arteko elkarreragina ulertuz eta kontuan hartuz.

Edonola ere, ezin da ahantzi eremu eleaniztunetako hizkuntzen arteko botere harremanak konplexuak izan daitezkeela. Konplexutasun horrek, gainera, eragina izan dezake hizkuntza politiketan, eta politika horiek, aldi berean, hizkuntzaren ikas-irakaskuntza prozesuan zein erabileran. Konplexutasun hori lan honen emaitzetan ere antzeman daiteke: partaideen $\%$ 85en ama-hizkuntza euskara den arren edo, haien ustez, \% 73,7k idazteko erraztasun handiena euskaraz duen arren, gaztelaniaz puntuazio altuagoa dute beren ekoizpen idatzien ebaluazioan (gaztelaniaz 85,10 eta euskaraz 83,45).

Eremu eleaniztun hauetako eskola testuinguruan bertakoa den hizkuntza gutxitua (gurean euskara), hizkuntza nagusia (gaztelania) eta egun lingua franca (ingelesa) deiturikoa ikasten dute kasu anitzetan. Horrela, hizkuntza gutxituen mantentze eta biziberritzea xedeetako bat duten eskolek 
hizkuntzak erakusteaz gain, hizkuntza gutxituaren ezagutza zein erabilera bermatu behar dute. Zenbait kasutan, azken helburu hori ezinbertzekoa da hizkuntzaren egoera soziolinguistikoa orekatzeko, testuinguru batzuetan hizkuntza nagusiak eremu gehienak bereganatzen baititu eta ezin baita bermatu hizkuntza gutxituan oinarrizko komunikazio gaitasunak elkarreragin sozial eta informalen bidez ikasi eta garatuko direnik. Hizkuntza gutxituek, gainera, globalizaziotik eta populazioaren mugimenduetatik eratorritako erronka berriak dituzte begi-bistan. Horren aitzinean, eskola testuinguruak ahalegin berezia egin behar du egoerari egokitzeko eta erronka berri hauei erantzuteko, iraganean hizkuntza gutxituak bultzatzeko eraginkorrak izan diren ideologiak egungo egoerara egokituz (Cenoz eta Gorter, 2017).

Testuinguru hori kontuan izanik, zenbait ikertzailek translanguaging praktika ikasgela barrura eramatea proposatu dute. Translanguaging terminoak hiztun eleaniztunak bere jardunean zenbait hizkuntza partekatzeari egiten dio erreferentzia. Terminoa 80ko hamarkadako Galeseko hezkuntza sistema elebidunetik dator, baina ordutik terminoa anitz hedatu da (ikusi Cenoz eta Gorter, 2017, 2019; Cummins, 2017; García, 2009; García eta Li Wei, 2014; Otheguy, García eta Rey, 2015; Sayer, 2012). Cenoz eta Gorter-ek (2019), errate baterako, honela definitzen dute termino hau: «today, it often serves as the umbrella term that embraces a wide variety of theoretical and practical examples of fluid use of languages breaking with a strict separation ideology both outside and inside school» (Cenoz eta Gorter, 2019, 133. or.). Autoreen arabera, tokian tokiko testuinguru soziala kontuan hartzea erabakigarria da translanguaging lantzeko orduan, batez ere hizkuntza gutxituen kasuan. Izan ere, komunitate gutxituen testuinguruetan, translanguagingaren erabilerak hizkuntza nagusiaren hiztunak ahaldundu ditzake, hizkuntza gutxituaren hiztunen kaltean. Horregatik, autoreek beharrezkotzat ikusten dute hizkuntza gutxituari bereak izanen dituen zenbait eremu egokitzea. Cenoz eta Gorter-ek $(2017,2019)$ ondorengo bortz oinarri proposatzen dituzte hizkuntza gutxitu bat edo bat baino gehiago erabiltzen diren eskola testuinguruetan translanguagingaren erabilera garatzeko: (1) hizkuntza gutxituarentzako arnasgune funtzionalak diseinatzea; (2) translanguagingaren bidez hizkuntza gutxitua erabiltzeko beharra garatzea; (3) hiztun berri eleaniztunen baliabideak erabiltzea gaitasun metalinguistikoa garatzeko eta, horrela, hizkuntza guztiak indartzeko; (4) hizkuntzen inguruko kontzientzia garatzea; (5) berezko translanguaginga (spontaneous translanguaging) ariketa pedagogikoekin lotzea. Edonola ere, proposaturiko praktika horrek testuinguru jakin bateko komunitate gutxitu bat indartu dezakeen arren, ez du erran nahi testuinguru orotan eragin berdina izanen lukeenik. Lekuan lekuko testuinguruaren azterketaren eta egokitzapenaren behar horrek translanguagingak izan ditzakeen inplikazioen azterketa eta behaketa sakona eskatzen du, beraz: «that calls for a careful and detailed examination of the implications of translanguaging as related to minority languages and for adapting translanguaging pedago- 
gies to the social contexts of the communities where the schools are located» (Cenoz eta Gorter, 2019, 134. or.). Oraindik ere praktika horren inguruko ikerketan bide luzea egiteke dagoen arren, badaude praktika hau gure hezkuntza-sisteman aplikaturik egin diren zenbait ikerketa (ikusi Cenoz eta Gorter, 2020; Cenoz eta Santos, 2020; Doiz eta Lasagabaster, 2017; Gorter eta Arocena, 2020; Leonet, 2018, 2019; Leonet, Cenoz eta Gorter, 2017, 2020).

\subsection{Mugak eta ikerketa hobetzeko proposamenak}

Ikerketa honek mugak ere izan baditu. Lagina 20 ikasletara mugatua dago, hots, 20 ikasle horiek hizkuntza-jardun eta errealitate soziolinguistikora. Horren erakusleetako bat dugu lanaren jardunean ikasleen ama-hizkuntzaren inguruko aniztasun urria muga izan dela ikerketa-galderak finkatzeko aldagai egokiak aukeratzeko orduan.

Horregatik, interesgarria izanen litzateke errealitate soziolinguistiko zabalago bateko partaideen laginak erabiltzea, aniztasun handiagoa izan eta, beraz, errealitateari hobeki egokituak. Era berean, gure laneko transferentziak kontuan hartuz, interesgarria izanen litzateke transferentzia horien norabidea aztertzea, hau da, identifikatutako transferentzia bakoitza hiztunaren zein hizkuntzatatik datorren analizatzea. Hiru hizkuntzen ebaluazio holistikoan adierazgarriak diren puntuazioetan sakontzea ere lerro interesgarria izanen litzateke, horien nolakotasuna hobeto ulertu eta aztertzeko.

Halaber, idatzizko ekoizpenez gain ahozko ekoizpenak aztertzeari ere interesgarri deritzogu. Hizkuntza-ekoizpen mota bakoitzak berariazko dituen ezaugarriak ditu eta hiztunak bere hizkuntzak aldaera desberdinetan erabiltzen ditu. Esparrua zabaldu eta hizkuntzen elkarreragina testuinguru bakoitzean nola gauzatzen den aztertzeak emaitza eta datu interesgarri eta esanguratsuak emango lituzke hiztun eleaniztunen jardun linguistikoa bere osotasunean ulertu eta azaltzeko.

\section{ERREFERENTZIAK}

Arocena, M.E. (2017). Multilingual Education: Teacher's beliefs and language use in the classroom [Doktorego tesia, Euskal Herriko Unibertsitatea]. ADDI Artxibo Digitala Ikerketa eta Irakaskuntza. Interneten eskuragarri: https://addi. ehu.es/handle/10810/25839

Berman, R. (1994). Learners' Transfer of Writing Skills Between languages. TESL Canada Journal / Revue TESL du Canada, 12(1), 29-46.

Bouvy, C. (2000). Towards the construction of a theory of cross-linguistic transfer. In J. Cenoz \& U. Jessner (arg.), English in Europe: The Acquisition of a third language (143-156). Clevedon: Multilingual Matters. 
Cenoz, J. (2001). The effect of linguistic distance, L2 status and age on crosslinguistic influence in L3 acquisition. In J. Cenoz, B. Hufeisen \& U. Jessner (arg.), Cross-linguistic Influence in Third Language Acquisition. (8-20). Clevedon: Multilingual Matters.

Cenoz, J. (2003). The Role of Typology in the Organization of the Multilingual Lexicon. In J. Cenoz, B. Hufeisen, \& U. Jessner (arg.), The Multilingual Lexicon (103-166). Dordrecht: Kluwer. http://dx.doi.org/10.1007/978-0-30648367-7_8

Cenoz, J. (2015). Content-based instruction and content and language integrated learning: the same or different?. Language, Culture and Curriculum, (28)1, 8-24. https://doi.org/10.1080/07908318.2014.1000922

Cenoz, J., \& Gorter, D. (2011). Focus on Multilingualism: A Study of Trilingual Writing. The Modern Language Journal, 95, 356-369. https://doi.org/10.1111/ j.1540-4781.2011.01206.x

Cenoz, J., \& Gorter, D. (2014). Focus on Multilingualism as an approach in educational contexts. In A. Creese \& A. Blackledge (arg.), Heteroglossia as a practice and pedagogy (239-254). Berlin: Springer.

Cenoz, J., \& Gorter, D. (2017). Minority languages and sustainable translanguaging: threat or opportunity?. Journal of Multilingual and Multicultural Development, 38(10), 901-912. http://dx .doi.org/10.1080/01434632.2017.1284855

Cenoz, J., \& Gorter, D. (2019). Multilingualism, Translanguaging, and Minority Languages in SLA. The Modern Language Journal, 103 (Supplement 2019), 130-135. https://doi.org/10.1111/modl.12529

Cenoz, J. \& Gorter, D. (2020). Teaching English through pedagogical translanguaging. Special Issue: World Englishes and Translanguaging, 39(2), 217-366.

Cenoz, J. \& Santos, A. (2020). Implementing pedagogical translanguaging in trilingual schools. System, 92, 1-9. https://doi.org/10.1016/j.system.2020.102273

Chomsky, N. (1957). Syntactic Structures. The Hague: Mouton.

Cummins, J. (2017). Teaching for transfer in multilingual school contexts. In O. García, A. Lin, \& S. May (arg.), Bilingual and Multilingual Education, Encyclopedia of Language and Education (103-115). Berlin: Springer.

De Angelis, G. (2007). Third or additional language acquisition. Clevedon, UK: Multilingual Matters.

De Angelis, G., \& Selinker, L. (2001). Interlanguage Transfer and Competing Linguistic Systems in the Multilingual Mind. In J. Cenoz, B. Hufeisen, \& U. Jessner (arg.), Cross-Linguistic Influence in Third Language Acquisition: Psycholinguistic Perspectives (42-58). Clevedon: Multilingual Matters.

Dewaele, J. (1998). Lexical Inventions: French Interlanguage as L2 versus L3. Applied Linguistics, 19(4), 471-490. https://doi.org/10.1093/applin/19.4.471

Doiz, A., \& Lasagabaster, D. (2017). Teachers' beliefs about translanguaging practices. In C. Mazak \& K. Carroll, (arg.)., Translanguaging in Higher Education. Beyond Monolingual Ideologies, (157-176). Bristol: Multilingual Matters.

Forsyth, H. (2014). The Influence of L2 Transfer on L3 English Written Production in a Bilingual German/Italian population: a study of a syntactic errors. Open Journal of Modern linguistics, 4, 429-456. http://dx.doi.org/10.4236/ ojml.2014.43036 
García, O. (2009). Bilingual Education in the 21st Century: A Global Perspective. Malden, MA and Oxford: Wiley/Blackwell.

García, O., \& Wei, L. (2014). Translanguaging: Language, Bilingualism and Education. New York: Palgrave Macmillan.

Gass, S. \& Selinker, L. (1983). Language Transfer in Language Learning. Rowley, MA: Newbury House.

Gorter, D., Zenotz, V., Etxague, X., \& Cenoz, J. (2014). Multilingualism and European minority languages: the case of Basque. In D, Gorter, V. Zenotz \& J. Cenoz (arg.), Minority languages and multilingual education: bridging the local and the global (278-301). Berlin: Springer.

Gorter, D., Arocena, E. (2020). Teachers' beliefs about multilingualism in a course on translanguaging. System, 92, 1-10. https://doi.org/10.1016/j.system.2020.102272

Hammarberg, B. \& Hammarberg, B. (1993). Articulatory re-setting in the acquisition of new languages. In Strangert, E., Heldner, M. \& Czigler, P. (arg.), Studies presented to Claes-Christian Elert on the occasion of his seventieth birthday: Studies presented to Claes-Christian Elert on the occasion of his seventieth birthday (61-67). Umeå: University of Umeå.

Hammarberg, B. (2001). Roles of L1 and L2 in L3 Production and Acquisition. In J. Cenoz, B. Hufeisen, \& U. Jessner (arg.), Cross-Linguistic Influence in Third Language Acquisition: Psycholinguistic Perspectives (21-41). Clevedon: Multilingual Matters.

Jacobs, H.L., Zinkgraf, S.A., Wormuth, D.R., Hartfiel V.F., Hughey, J.B. (1981). Testing ESL Composition; a Practical Approach. Rowley, MA: Newbury House.

Jessner, U. (2008). Teaching Third Languages: Findings, Trends and Challenges. Language Teaching, 41, 15-56. http://dx.doi.org/10.1017/ S0261444807004739

Kellerman, E. (1995). Cross-Linguistic Influence: Transfer to Nowhere? Cambridge University Press, Cambridge, Annual Review of Applied Linguistics, $15,125-150$.

Kobayashi, H. \& Rinnert, C. (2012). Understanding L2 writing development from a multicompetence perspective: Dynamic repertoires of knowledge and text construction. In R. M. Manchon (arg.), L2 writing development: Multiple perspectives (101-134). Berlin: De Gruyter Mouton.

Leonet, O. (2018). Focus on multilingualism» eta bere aplikazio didaktikoa eskola testuinguruan [Doktorego tesia, Euskal Herriko Unibertsitatea]. ADDI Artxibo Digitala Ikerketa eta Irakaskuntza. Interneten eskuragarri: https://addi. ehu.es/handle/10810/36126

Leonet, O. (2019). Translanguaging-ikuspegia lehen hezkuntzako ikasgelan. Ba al du eraginik ikasleen euskara-mailan? TANTAK, 31(1), 81-101. https://doi. org/10.1387/tantak.20248

Leonet, O., Cenoz, J., \& Gorter, D. (2017). Challenging Minority Language Isolation: Translanguaging in a Trilingual School in the Basque Country. Journal of Language, Identity \& Education, 16(4), 216-227. https://doi.org/10.1080/15 348458.2017.1328281

Leonet, O., Cenoz, J., \& Gorter, D. (2020). Developing morphological awareness across languages: translanguaging pedagogies in third language acquisition. Language Awareness, 29(1), 41-59. https://doi.org/10.1080/09658416.2019.1 688338 
Nafarroako Gobernua, Euskarabidea. (2017). 16-19.eus. I Plan estratégico del euskera (2016-2019) (1st ed.). Iruña, Pamplona: Instituto Navarro del Euskera - Euskarabidea.

Odlin, T. (1989). Language transfer. Cross-linguistic influence in Language Learning. Cambridge, UK: Cambridge University Press.

Orcasitas, M. (2018). Hiru hizkuntzatan idazten: hurbilpen holistiko, analitiko eta hizkuntza artekoa [Doktorego tesia, Euskal Herriko Unibertsitatea]. ADDI Artxibo Digitala Ikerketa eta Irakaskuntza. Interneten eskuragarri: https://addi. ehu.es/handle/10810/34609

Ortega, L. (2019). SLA and the study of equitable multilingualism. Modern Language Journal, 103, (Supplement 2019), 23-38.

Ortega, L., \& Carson, J. (2010). Multicompetence, social context, and L2 writing research praxis. In T. Silva \& P. K. Matsuda (arg.), Practicing theory in second language writing (48-71). West Lafayette: IN Parlor Press.

Otheguy, R., García, O., \& Reid, W. (2015). Clarifying translanguaging and deconstructing named languages: A perspective from linguistics. Applied Linguistics Review, 6(3), 281-307. https://doi.org/10.1515/applirev-2015-0014

Real Academia Española (2001). Diccionario de la lengua española. Interneten eskuragarri: https://dle.rae.es/cultura?m=form [Kontsulta eguna: 2020/09/09].

Rothman, J., \& Cabrelli, J. (2010). What variables condition syntactic transfer? A look at the initial state. Second Language Research, 26(2), 189-218.

Rothman, J. (2010). On the typological economy of syntactic transfer: Word order and relative clause attachment preference in L3 Brazilian Portuguese. International Review of Applied Linguistics, 48(2-3), 245-273. https://doi. org/10.1515/iral.2010.011

Rothman, J. (2011). L3 Syntactic Transfer Selectivity and Typological Determinacy: The Typological Primacy Model. Second Language Research 27(1), 107-127. https://doi.org/10.1177/0267658310386439

Rothman, J. (2013). Cognitive economy, non-redundancy and typological primacy in L3 acquisition: Evidence from initial stages of L3 Romance. In S. Baauw, F. Dirjkoningen \& M. Pinto (arg.), Romance languages and linguistic theory 2011 (217-247). Amsterdam: John Benjamins.

Rothman, J. (2015). Linguistic and cognitive motivations for the Typological Primacy Model (TPM) of third language (L3) transfer: Timing of acquisition and proficiency considered. Bilingualism: Language and Cognition 18(2), 179-190. https://doi.org/10.1017/S136672891300059X

Sayer, P. (2012). Translanguaging, TexMex, and bilingual pedagogy: Emergent bilinguals learning through the vernacular. Tesol quarterly, 47(1), 63-88. https://doi.org/10.1002/tesq.53

Schwartz, B., \& Sprouse, R. (1996). L2 cognitive states and the Full Transfer/ Full Access model. Second Language Research, 12(1), 40-72. https://doi. org/10.1177/026765839601200103

Selinker, L., \& Lakshmanan, U. (1993). Language Transfer and Fossilization: The Multiple Effects Principle. In S. Gass, \& L. Selinker (arg.), Language Transfer in Language Learning (197-216). Philadelphia: Benjamins.

Sharwood-Smith, M. (1994). Second Language Learning. Theoretical Foundations. London: Longman. 
Soltero-González, L., Escamilla, K., \& Hopewell, S. (2012). Changing teachers' perceptions about the writing abilities of emerging bilingual students: towards a holistic bilingual perspective on writing assessment. International Journal of Bilingual Education and Bilingualism, 15(1), 71-94. https://doi.org/10.1080/13670 050.2011 .604712

Vainikka, A., \& Young-Scholten, M. (1996). Gradual development of L2 phrase structure. Second Language Research, 12(1), 7-39. https://doi. org/10.1177/026765839601200102

Velasco, P., \& García, O. (2014). Translanguaging and the Writing of Bilingual Learners. Bilingual Research Journal, 37(1), 6-23. https://doi.org/10.1080/15 235882.2014.893270

Wei, L., \& Wu, C. (2009). Polite Chinese children revisited: creativity and the use of codeswitching in the Chinese complementary school classroom. International Journal Of Bilingual Education And Bilingualism, 12(2), 193-211. https:// doi.org/10.1080/13670050802153210 